\title{
Contributions to Neuroembryology of Santiago Ramon y Cajal (1852-1934) and Jorge F. Tello (1880-1958)
}

\author{
LUIS PUELLES* \\ Department of Human Anatomy and Psychobiology, Faculty of Medicine, \\ University of Murcia and CIBERER-U736, Murcia, Spain
}

\begin{abstract}
The contributions of Cajal to Neuroembryology are glossed with the help of a selection of images extracted from Cajal's (1929) own synthesis of his neuroembryological output, laying emphasis on the persisting relevance and unsurpassed quality of many individual achievements and milestones he delivered on neurohistogenesis, practically throughout his career. Cajal's theoretical background as regards embryology, morphology, comparative neuroanatomy and evolution is sketched at the beginning. The body of the review is divided into sections covering spinal cord, cerebellum, cortex, retina, sensory organs and muscular terminals, and astroglia. The deep and common-sensical conceptual analysis of neural histological variation during development performed by Cajal is highlighted at several points, as well as the places where he advanced genial conjectures that reached far forward in time, placing him still at the front of present day neuroembryological thinking. Some errors committed by Cajal are also commented upon. At one point (the retina), some of the present author's own observations with a Golgi method variant are presented, as they complement observations that Cajal left incomplete because of technical problems. The major neuroembryological works of Cajal's pupil Jorge F. Tello are mentioned at the end.
\end{abstract}

KEY WORDS: neurohistogenesis, neuronal differentiation, axon growth, growth cone, neurotropism

\section{Introduction}

Cajal's school was not properly neuroembryological, in the sense that the major research emphasis of both master and pupils was placed in exploring the cellular structure of adult brains, rather than neural developmental processes. However, already during his early efforts in Valencia to acquire experience with the chromo-argentic method of Golgi, Cajal found that use of immature postnatal or embryonic material frequently generated useful preparations. This "immature structure approach", which he developed subsequently to fruition in Barcelona, highlighted serendipituously a number of developmental processes, apart of helping to understand the complex texture of the adult brain. In the master's words, this method showed "the growing trees in isolation, before they build up an impenetrable forest". Ulterior introduction and practical exploration of the reduced silver staining method for neurofibrils (in Madrid) also produced optimal results in embryonic material. Therefore, Cajal often studied embryonic or young postnatal brains (chick, pigeon, duck, mouse, rat, rabbit, hamster, cat, dog, veal). His accurate morphological eye fell upon a sizeable number of details that expanded or corrected contem- poraneous developmental knowledge (as represented, for instance, in the treatise of Kölliker, 1884, or the works of His, 1888, 1890, 1892, 1893, 1904 and von Kupffer, 1906). This endeavour famously led to upholding neuronal theory against defenders of reticularism (Ramon y Cajal, 1933; reprinted in 1952), but also produced unsurpassed flashes of novel histogenetic understanding in all regions of the brain upon which Cajal concentrated (Ramon y Cajal, 1929).

Cajal intuitively dealt with neuronal morphology in a strikingly dynamic and poetic way. He saw through the microscope adult contacting neurons -"mysterious butterflies of the soul"- as delicately talking to each other (even embracing and kissing each other). He imagined fluxes of information passing from dendrites to axons, leading to his doctrine of dynamic polarity of neurons. He interpreted embryonic neuronal forms as glances at fluid sequences of shapes, bespeaking of differentiation, axonal and dendritic growth, and cell migration. He eventually was proven to be right in most of these intuitions.

Cajal did not pursue either systematic comparative analysis of the structures he investigated, but pragmatically took in assorted avian and mammalian data (also some results on lizards, frogs

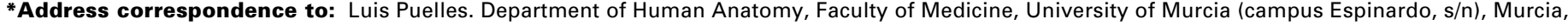
E30071, Spain. Tel: +34-868-884-342. Fax: +34-868-8833-955. e-mail: puelles@um.es
} 

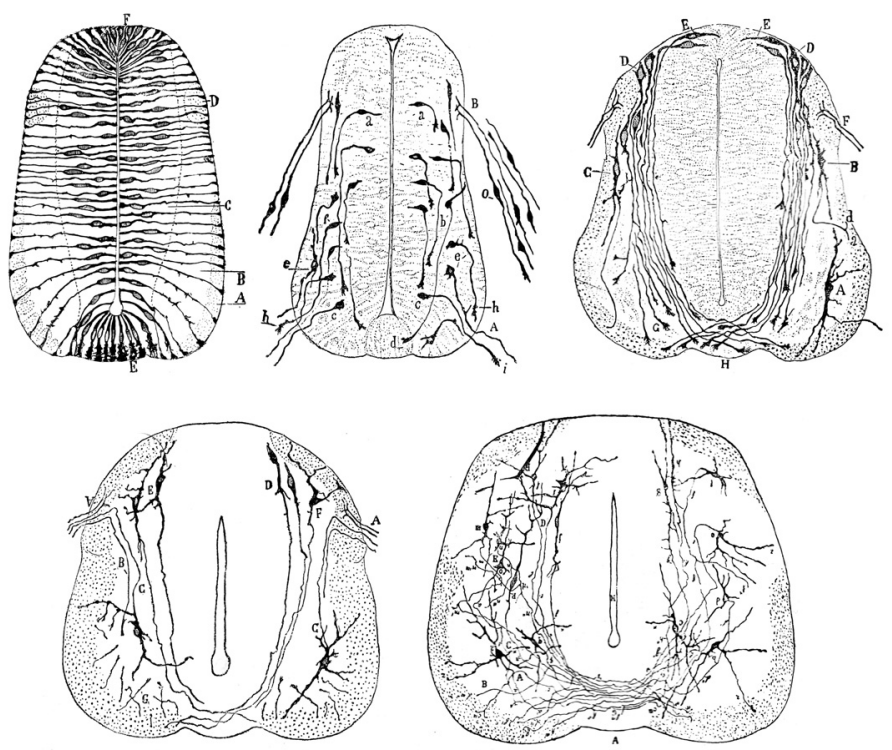

Fig. 1. Golgi impregnated spinal cord of chick embryos. Images drawn after 3-10 days of incubation, illustrating neuroepithelial structure of the spinal cord and the differentiation of early neurons (motor, sensory and interneuronal), as they sort out of the ventricular zone, formed by the cell bodies of the neuroepithelial progenitor cells (spongioblasts), and migrate into the incipient mantle layer. Note the growing axons are preceded by axonal growth cones, many of them attracted by the floorplate. At later stages, development of dendritic processes and repositioning of the somata.

and fish, obtained with the help of his younger brother Pedro Ramon y Cajal, or his pupil J.F.Tello). These he interpreted jointly within a vast, unformulated assumption of regional field homology and recapitulative evolution, probably rooted in L. Edinger's and E. Haeckel's work (.".will developmental sequential analysis of neurons not reveal an echo or recapitulation of the dramatic history lived by neurons in their millenary endeavours through the animal series?", Ramon y Cajal, Recuerdos de mi vida: Historia de mi labor cientifica, 1981). Essential correspondence in cerebral topology, invariant neighborhood relationships with surrounding tissue elements, and similarity in shape of the cell forms he observed in different vertebrates were sufficient proof for him
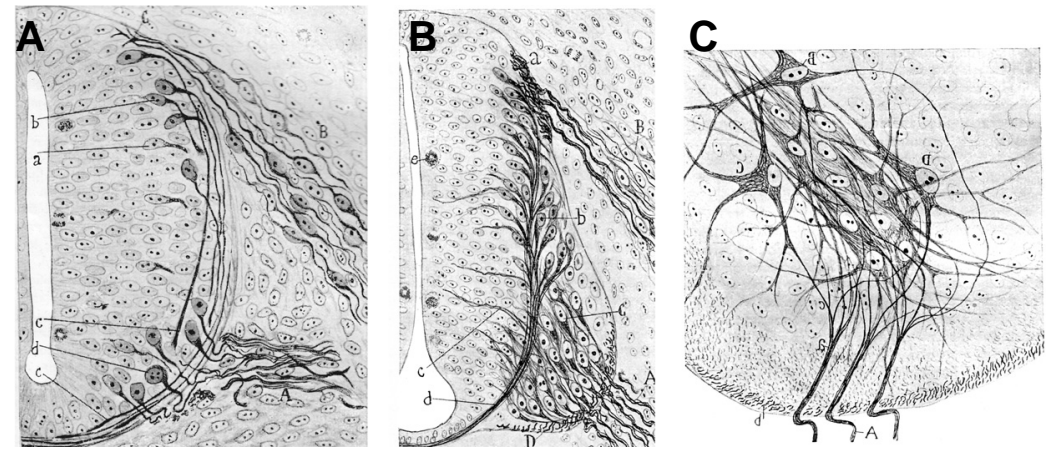

Fig. 2. Reduced-silver preparations of chick embryo spinal cord after 3-5 days of incubation. Note afferent sensory fibers (dorsal root) and efferent motor axons (ventral root) of a spinal nerve. (C) A higher magnification view of differentiating motoneurons in the ventral horn. that he was describing "the same" cells in different animals (spinal cord, brainstem, cerebellum, optic tectum, thalamus, hypothalamus, retina, cortex). He obviously supported evolutionary theory.

Cajal stood upon standard ground as regards his general morphological conception of the developing neural tube. Here, again, Cajal was more interested in the cellular details than in the shape and topology of the brain parts containing the cells. He never discussed the length axis of the brain, the anteroposterior neural compartments (vesicles, neuromeres), nor the precise delimitation and fates of the longitudinal zones (floor, basal, alar and roof plates of His, 1893, 1904). He showed practically no acknowledgement of contemporaneous literature on neuromeres or neural segments (a pattern also found in His and Kölliker). However, he collected, read and annotated profusely His' and von Kupffer's works (the latter was a major defender of neural segmentation; see von Kupffer, 1906), and cited them jointly with regard to neurogenesis; therefore, he must have been aware of these conceptions. Interestingly, his close collaborator J.F.Tello used straightforwardly the concept of neuromeres in his work on early chick and mouse neurogenesis, most of which was done while the Master was still alive. This probably means that Tello counted with his approval (Tello, 1925, 1934).

Amongst Cajal's pupils, J.F.Tello was the one most devoted to neuroembryology. On the other hand, P.del Rio-Hortega famously first examined developmental aspects of microglia and oligodendroglia, the two glial cell forms he discovered (development of radial and free astroglia was treated by Cajal,1890d and in various ulterior works).

\section{Cajal's neuroembryological contributions}

I'll organize this commented account not chronologically, but following Cajal's own thematic system in the compendium "Etudes sur la neurogenese de quelques vertebres" (Ramon y Cajal, 1929), where the grouped individual publications are reprinted in French. A separate section on astroglia is appended at the end. Most of the illustrations are taken from the same work just cited, where further details about species, age, etc. can be found. Note that I will not comment here on Cajal's extensive work on degeneration and regeneration in the nervous system (Ramon y Cajal, 1913, 1914 and elsewhere).

\section{Neuronal differentiation and spinal cord}

Stimulated by the description with conventional histological methods of piriform neuroblasts in the human embryonic spinal cord (His, 1887, 1889), Cajal decided early on to describe the morphology and differentiation sequence of spinal cord neuroblasts (i.e., young postmitotic neurons) and neuronal processes using Golgi's method (Ramon y Cajal, 1889, 1890a,b). To this end, he examined the cervical and dorsal spinal cord of chick embryos fixed between 3-10 days of incubation. The rostrocaudal gradient of maturation found across the spinal cord must have helped the dynamic interpretation of differentiation sequences. Observations at 3-4 days of incubation readily showed immature motoneurons in the basal plate (ventral horn), as well as alar (dorsal horn) postmitotic neurons in the process of sorting out from the ventricular zone ("layer 

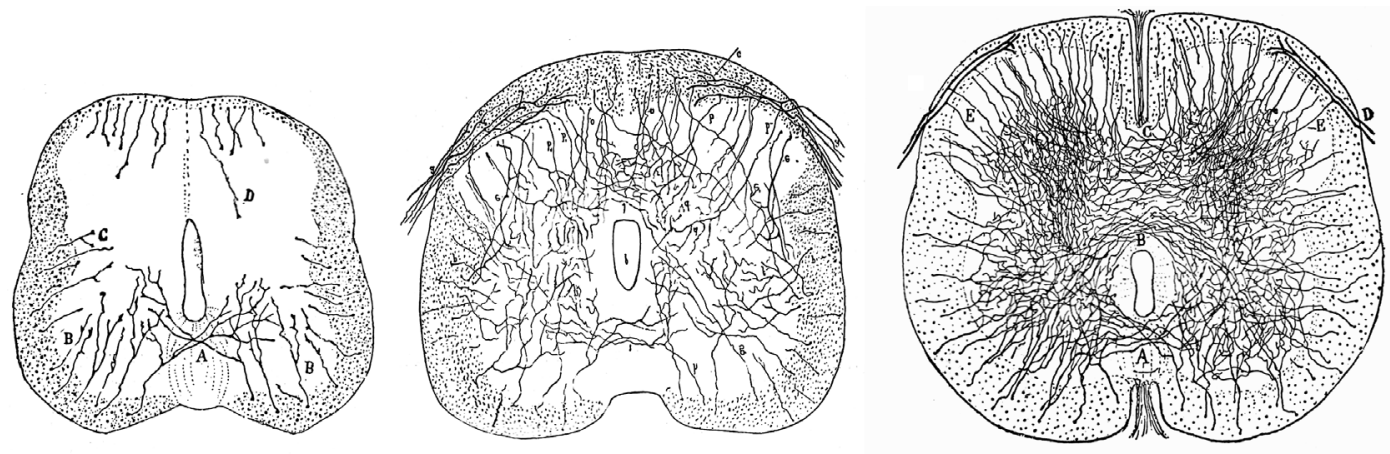

Cajal, 1929), but his early conjecture was essentially right.

The earliest formation of radially penetrating collaterals from the spinal white matter and the sensory roots into the ventral or dorsal horns in the chick ( 5 days and 7 days of incubation, respectively) attracted Cajal's (1890a,b) attention. These collateral axon terminals (arising at the Ranvier nodes of the myelinated

Fig. 3. Terminals penetrating spinal gray matter. Three stages in the penetration and arborization of terminals from the surrounding white matter and the dorsal roots in the spinal gray matter (chick embryo; 7, 9 and 10 days of incubation; Golgi). cordonal fibers) were also preceded by minute axonal growth cones (Fig. 3). Their full ar-

of spongioblasts") and growing their axons towards and across the anterior spinal commissure (Fig. 1). At the time it was widely thought on the authority of $\mathrm{His}(1887,1889)$ that the spongioblasts and neuroblasts were entirely independent cell types, the latter stemming from rounded germinative cells at the ventricular surface. Cajal apparently accepted this analysis. However, we now know that such rounded elements are metaphase cell forms of the neuroepithelial ventricular cells (the old spongioblasts), as was deduced by the heterodox Schaper (1897).

The axons of immature neuroblasts were uniformly preceded by axonal growth cones, first described, named and correctly interpreted as transient highly dynamic structures by Cajal in these studies (Figs. 1,3,4). Some axons bifurcated and possessed accordingly two growth cones. He distinguished thanks to Golgi's impregnation method that axonal growth cones are decorated by variable smaller cytoplasmic processes that penetrate the "interstitial cement", referring to what we now call filopodia and foliopodia. Later, Cajal noted that these filopodia are invisible with neurofibrillar stains, since these only distinguish the central cytoskeleton of the growth cones (Fig. 4).

Older stages of the deduced differentiation sequences indicated subsequent perikarial translocation into the mantle layer of the immature spinal neuroblasts and progressive development of their dendritic processes, forming commissural, cordonal, efferent (motoneurons) and local circuit neurons, according to their location, axonal trajectories and mature dendritic typology (Fig. 1; Cajal, 1880, 1890a,b). Against the prevalent contemporaneous idea that neuroepithelial spongioblasts did not generate neurons (supposed to derive exclusively from the rounded "germinative cells" of His), Cajal (1890a) lucidly reasoned that neurons must also differentiate from spongioblasts (that is, from interkinetic ventricular cell forms), since otherwise it made no sense that the most immature postmitotic forms were similar in shape to spongioblasts (they had both apical- and basal-oriented cytoplasmic processes, and showed gradual reduction of the trailing apical or ventricular process). He later developed some doubts about the consistence of this idea on the basis of reduced silver data (Fig. 2; see his footnote 2, p.10 in borization in the spinal gray matter, characteristic for each axonal subgroup and each regional target, developed over the following days, eventually forming remarkably tight plexi, without the fibers ever losing their individuality (Fig. 3; Cajal, 1890b). He reflected that such terminals and also the targeted neuronal cell bodies remain unmyelinated to aid transmission of the "nervous excitation".

Cajal (1890b) noted that embryonic sensory ganglion cells of the chick were largely bipolar, in contrast to the monopolar ones he had observed in adult mammals. He mentioned, nevertheless, that the dendritic and axonal processes of some cells arise close to each other at one side of the cell body, or eventually even originate in others jointly from a pedicle (Fig. 5A). This is in fact an implicit early description of the developmental transformation of early bipolar ganglion cells into more mature pseudomonopolar forms, by progressive perikarial dislocation, described later by $\mathrm{His}$ (1904) and other authors, including himself (Ramon y Cajal, 1904, 1906). He also commented on the systematic behaviour of sensory dorsal root afferents (thin or thick), which bifurcate into ascending and descending branches in the dorsal column and Lissauer's tract, giving at intervals a variety of collaterals (Fig. 5B). He apparently was the first to observe that some of the thick fibers penetrate deeply into the anterior horn and contact directly motoneurons (Fig. 5A; we now know them to be propioceptive afferents).
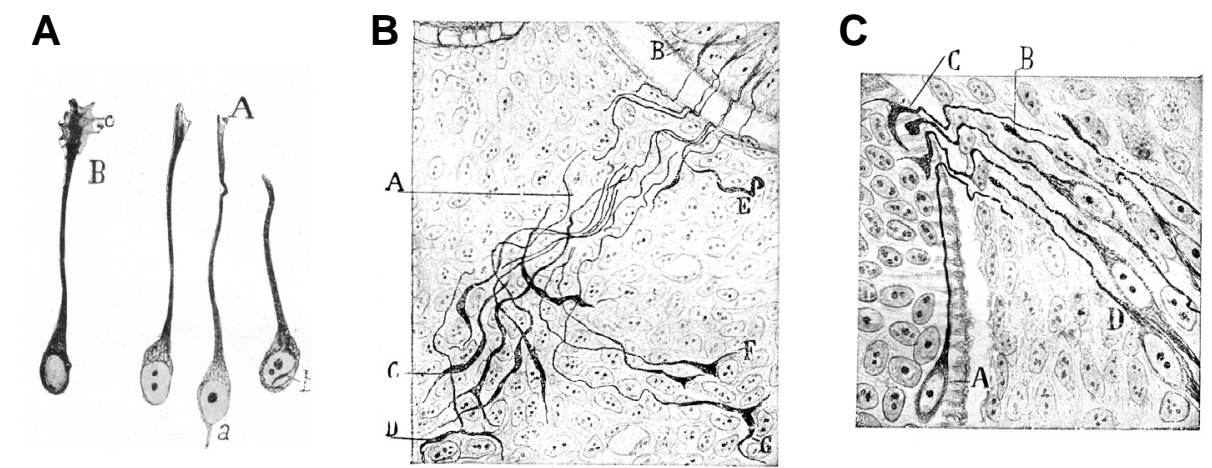

Fig. 4. Axonal growth cones. (A) Aspect of axonal growth cones after Golgi impregnation (cell $B$; filopodia and lamellipodia are visible) versus neurofibrillar stain (cells $A$; only the cytoskeletal component is visible). (B) Axonal growth cones of emerging motoneuron axons of a spinal ventral root, navigating through the mesenchyme. (C) Axonal growth cones of afferent sensory fibers of a dorsal root, entering the spinal cord (note fusiform shape of immature sensory ganglion cells). 
A

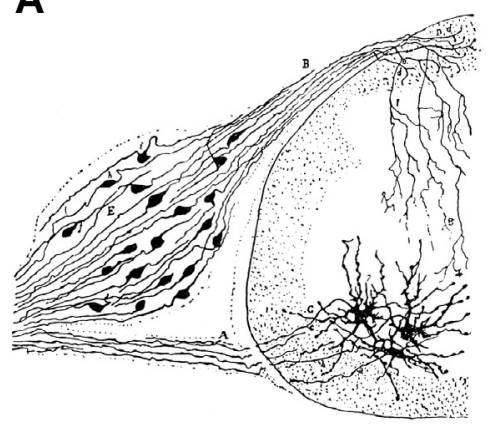

B

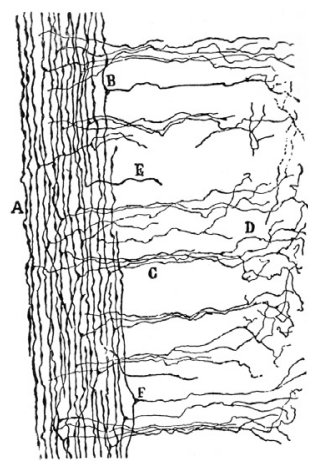

Fig. 5. Golgi-impregnated spinal cord. (A) Note the variety of cell forms in the sensory ganglion, indicating incipient adoption of the pseudomonopolar shape, by translocation of the cell body away from the primary fusiform shape. Some entering propioceptive afferents of the dorsal root reach the motoneurons in the ventral horn. (B) Sagittal section through the dorsal horn, showing the penetrating collaterals of the ascending and descending primary afferent fibers in the dorsolateral tract of Lissauer.

Subsequent studies on the embryonic avian and mammalian spinal cord (Ramon y Cajal, 1906, 1907, 1908) were done using the neurofibrillary method with reduced silver developed by him (Fig. 2), partly as a collateral result of his deep involvement in the technology of photographic emulsions (Ramon y Cajal, 1912b). These new results served to expand and substantiate by unobjectionable data and insightful discussion his support of the neuronal theory of His and Forel versus the opposed reticularist conceptions, a subject he addressed again in his later, all-encompassing review of this issue (Ramon y Cajal, 1933).

\section{Cerebellum}

A significant part of our knowledge on cerebellar cellular structure and histogenesis is due to Cajal (Figs. 6-9). He first described and named parallel, mossy and climbing fibers (Fig. 6) and their synaptic endings (Ramon y Cajal, 1888c, 1890d, 1894, 1911), as well as the basquets formed around Purkinje cells (Ramon y Cajal, $1889 \mathrm{e}, 1890 \mathrm{~d}, \mathrm{e}$ ) and the intraglomerular terminal axonal bouquets of Golgi cells in the inner granular layer. He also magistrally investigated the development of the cerebellar cortex, notably the differentiation sequence of granule cells, Golgi

cells, Purkinje cells and basquet cells (Ramon y Cajal, 1890a, 1890e).

Previous authors such as Vignal, Schwalbe and Obersteiner had wrongly interpreted the external granular cells either as derived from migrated leucocytes, or as mesenchymal cells producing interstitial matrix, radial fibers or basal membrane. Cajal noted that this outer cerebellar layer diminishes in thickness and then disappears as the molecular layer increases in depth and matures (Ramon y Cajal, 1889e). This already indicated to him that the external granular cells must participate in the development of deeper elements, but their study was handicapped by resistance of these minute immature cells to impregnation. Eventually he succeeded in visualizing them with the Golgi method in newborn dogs, rats and cats, as well as in advanced foetuses of cows and cats (Ramon y Cajal, 1890d). He found out that the external granular cells are disposed in two laminae (Figs. 7,8 center). The outer elements were extremely immature and had shapes suggesting an ectodermal germinative nature. Cajal observed abundant mitotic figures in this lamina (nowadays we know they do proliferate, representing one of the exceptional cases where neural proliferation occurs extraventricularly, a process that continues into postnatal life; Fujita et al., 1966). In the subjacent lamina there appeared slightly more differentiated granular cells with cell bodies disposed parallel to the transversal cerebellar folia (Cajal curiously labels this arrangement as being "longitudinal", though he was not referring to the neural tube axis, but to the axis of the folia, which is transversal to the brain axis). These postmitotic neurons displayed a horizontal bipolar shape with long processes growing at either end. The deepest cells had in addition a radially penetrating protoplasmic process ending freely in the molecular layer (Fig. 7). Parallel observations in the molecular layer revealed various radially disposed bipolar cell bodies at different depths which had a superficial ascending axon that bifurcated as it entered the deep external granular layer, and became continuous with one of its parallel fibers. A protoplasmic radial process originating at the deep pole of these cells traversed the deep molecular layer and even reached inwards past the Purkinje cell layer. These bipolar radial cells of the molecular layer were never found in the adult cerebellum. In his initial description of these cells the observed transitional forms with external granular neurons were too rare to fundament a single developmental sequence (Ramon y Cajal, 1890e). However, subsequent addi-
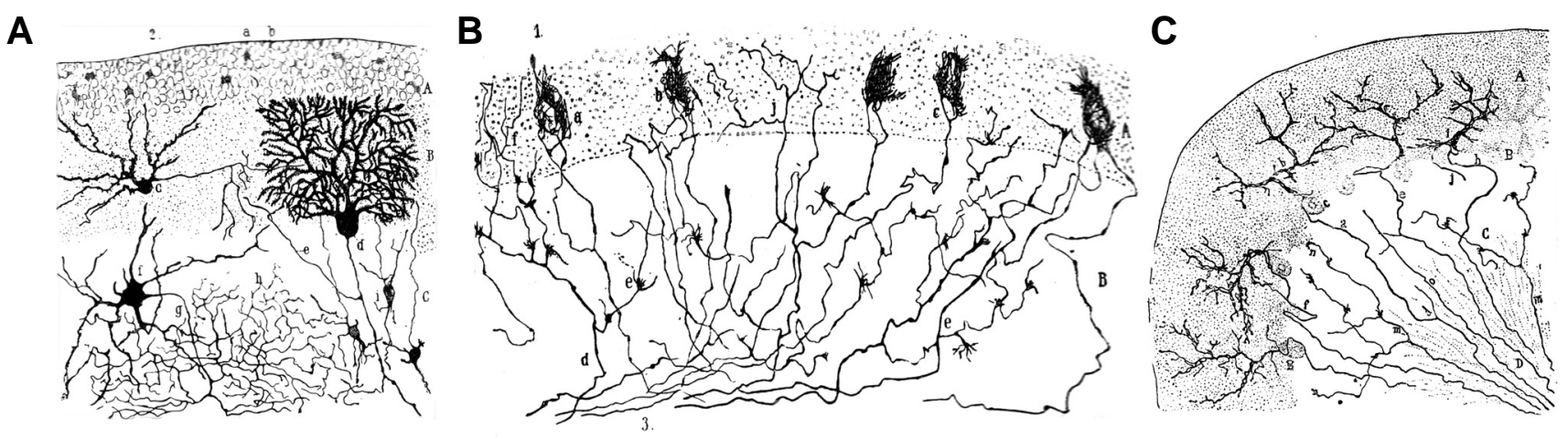

Fig. 6. Characteristic structural elements of the cerebellar cortex, after Golgi impregnation (sagittal plane). (A) A Purkinje cell, a basket cell, a Golgi neuron and three grains. Stellate cells are barely visible in the upper region of the molecular layer. (B) Immature mossy fibers (labeled B) and climbing fibers (labeled A) from a newborn dog. The latter form each a tight plexus over the soma of an immature Purkinje neuron. (C) Adult rat climbing fibers, apposed to the dendritic tree of Purkinje neurons (sagittal plane). 

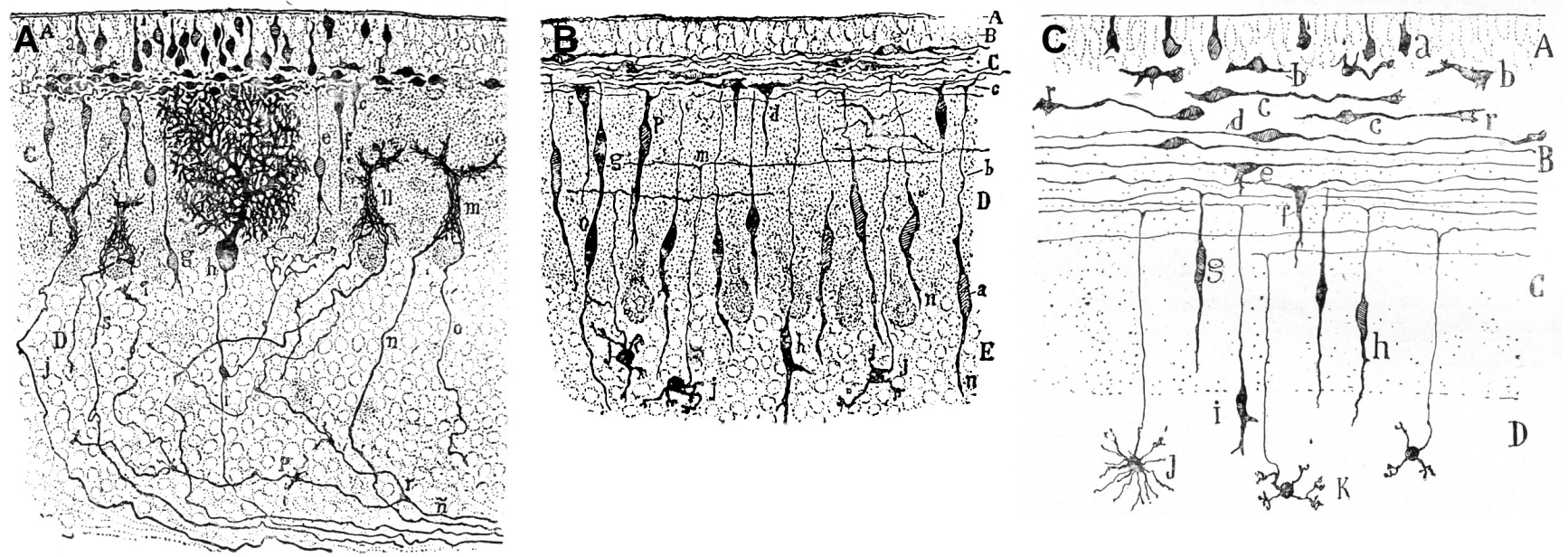

Fig. 7. Developing cerebellar grains and parallel fibers. (A) P16 dog, sagittal section (note dendritic tree of the Purkinje cell). The small proliferating cells of the outer granular later are Golgi-impregnated, as are the immature grains underneath as they grow the parallel fibers (not visible in this plane). Some fusiform vertical grains are migrating inwards across the molecular layer and the Purkinje cell layer, approaching the inner granular layer, and leaving their parallel fiber behind. Note also the climbing fibers starting to invade the Purkinje dendritic trees. (B) P12 rat, transversal section, illustrating the parallel fibers and the most immature tangential grain somata aligned with them, as well as more mature ones starting to drop into the molecular layer or crossing it. The most mature ones have reached already the inner granular layer and have developed the typical 3-4 small dendrites with terminal "hands" inserted into glomeruli, where they receive synaptic input from mossy fibers and Golgi-cell axon terminals. (C) An overall schema of the differentiation sequence of cerebellar grains in cross-section, according to Golgi impregnated material, as figured out by Cajal in 1890.

tional observations (obtained in the midst of a personal tragedy, the death of his young daughter, as he tells in his autobiography; Ramon y Cajal, 1981) finally led Cajal to deduce in a flash of insight that all these forms were transitional stages in the development of the inner granular cells of the cerebellum. This represents one of the most beautiful and complex examples of differentiation and migration sequence discovered by any morphologist by means of sheer descriptive analysis. Many years passed before these results were verified by experimental means (e.g., Forströnen, 1963; Rakic, 1971). As commented later in a footnote (Ramon y Cajal, 1929, p.188), his brother Pedro already sketched in 1891 these (Santiago's) ideas in a work on the brain of reptiles (P.Ramon, 1891). They were reported again by Cajal in a French translation of some conferences (Ramon y Cajal, 1894; an excerpt of this is contained in 1929; see Fig. 7C). Shortly afterwards, Lugaro reached independently the same conclusions, as did subsequently half a dozen other colleagues. Numerous European histologists were now following the example of the Spanish master in studying developing brains.

Other important results on cerebellar histogenesis resulted from the study of the development of the dendritic tree of Purkinje cells and the associated terminal plexus of climbing fibers (Ramon y Cajal, 1890d; 1904b). Both showed an initial stage of correlated excesive protoplasmic arborization around the immature migrated cell body (Fig. 8; Purkinje cells migrate earlier radially from the subventricular zone into the overlying cortical primordium).
A

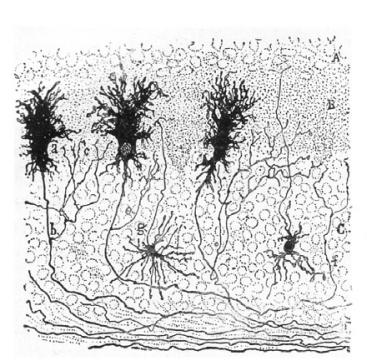

B

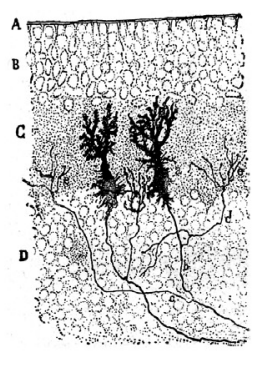

C

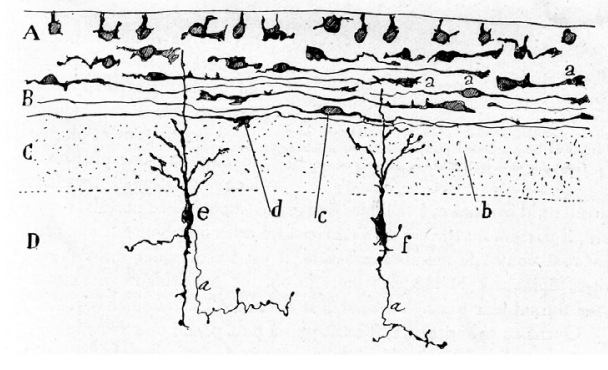

D

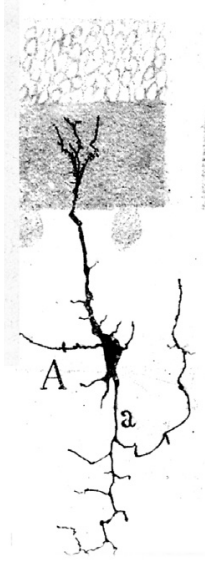

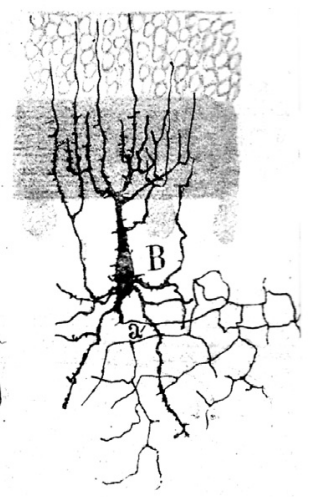

Fig. 8. Differentiation stages of Purkinje neurons and Golgi neurons of the cerebellum. Immature Purkinje cells (A,B) have an excess of perisomatic processes. As they mature, dendritic growth becomes progressively restricted to the apical single dendrite that penetrates the molecular layer. Note the recurrent collaterals of the Purkinje cell axons, and a pair of grains, which also produce initially an excess of dendritic branches, once they colonize the inner granular layer (compare with Fig. 7B). The Golgi neurons (C,D) are initially bipolar in shape and already show an incipient axon growing inside the inner granular layer (note also a number of immature outer grains). Later, the number of dendritic branches increases and the axon becomes richly ramified, contributing terminals to the glomeruli (not visible yet). 
Later most of such perisomatic processes are withdrawn while the main dendritic trunk expands radially in the molecular layer with its spinny branches, simultaneously flattenning in the sagittal plane (Fig.8; compare Fig. 7A). Coherent growth of both the dendrites and the attached plexus of climbing fibers (Fig. 6 B,C) suggested to the master they respond jointly to both a distal growth stimulus produced by the external granular cells and a stabilizing effect of the differentiating parallel fibers within the molecular layer (presumably starting synaptogenesis upon the spines). This was also an exceedingly rare and remarkably successful case of developmental analysis of an entire developing system, covering a neuron and all its afferents (Cajal's synthesis of direct and indirect input to Purkinje cells included not only parallel, mossy and climbing afferent fibers, but also the axons of stellate neurons upon distal dendritic branches and the pericellular bouquet of basquet neuron axons finishing upon the axonal cone, and even the recurrent collaterals of the Purkinje cell axon). Cajal also noted the correlated differentiation of inner granular cell dendrites (within cerebellar glomeruli or "cerebellar islets"), interlaced with the terminal arborizations of mossy fibers arrived somewhat earlier and the axon terminals of Golgi interneurons (Figs. 6-8).

Cajal first described as well the early development of the dendritic tree of Golgi neurons of the cerebellar cortex (Fig. 8D).

A

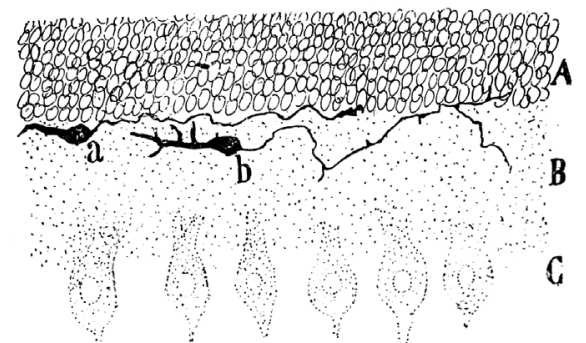

B

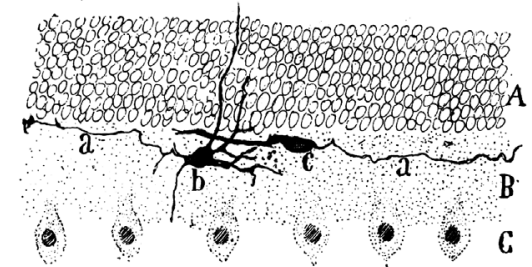

C

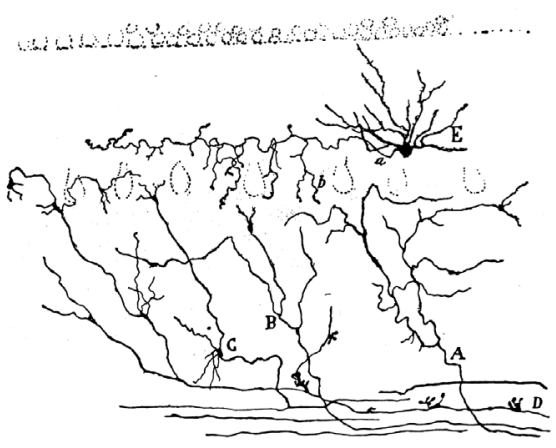

Fig. 9. Stages in the differentiation of cerebellar basquet neurons (sagittal plane). Note axon associated to the bodies of Purkinje cells, and gradual increase in dendritic branches. (C) A mature basket cell can be seen, whose axonal terminals contact the axonal hillock of Purkinje neurons; there are also some mossy fibers.

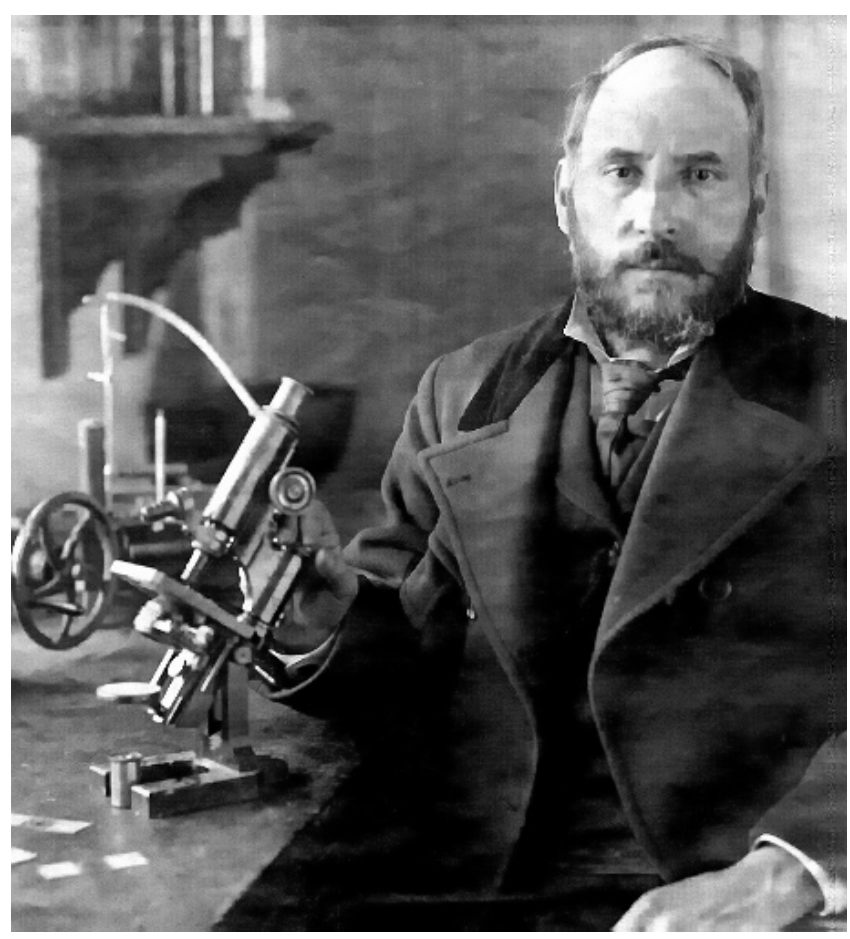

Fig. 10. Self-portrait of Cajal and his microscope. This corresponds to the time of his cerebellar discoveries.

The latter have initially a radial bipolar shape (single apical and basal dendrites) and their incipient axon grows into the inner granular layer. Later basal and apical dendrites ramify profusely, as does the axon in an even more massive way (Fig. 8D). The ascending dendritic branches that enter the molecular layer in increasing number show spines where they contact parallel fibers.

The differentiation sequence of basquet and stellate cells of the molecular layer was treated in tome I of the master's treatise (Ramon y Cajal, 1904c). These immature neurons are recognized by the orientation of their length axis perpendicular to the folia and to the parallel fibers. One pole is dendritic and the other axonal (Fig. 9). Since he believed that these neurons are formed sequentially from the external granular layer (a conjecture that was not corroborated by more recent experimental data, e.g., by clonal analysis; Mathis et al.,1997), Cajal deduced that the oldest ones are more mature, lie deeper in the molecular layer and transform into basquet neurons; these subsequently envelop the bodies of a series of Purkinje cells with their axon terminals (Fig. 9 bottom). Before doing this, numerous cases are observed in which the basquet cell axons perform irregular or curved trajectories, suggesting to Cajal a partial lack of navigational guidance until the Purkinje cell bodies attain a specific level of maturity. Smaller neurons lying more superficially in the molecular layer differentiate as stellate cells and contact with their axons the peripheral dendritic branches of the Purkinje cells. These apparently relatively younger elements appear in postnatal mammals as less differentiated (Fig. 6A). Cajal argued that these do not access with their axons the Purkinje cell bodies "because these are already occupied by the basquet neurons" (an early concept of competition for postsynaptic loci). Nowadays we would presume molecularly specific cellular interaction with the terminal dendrites of 

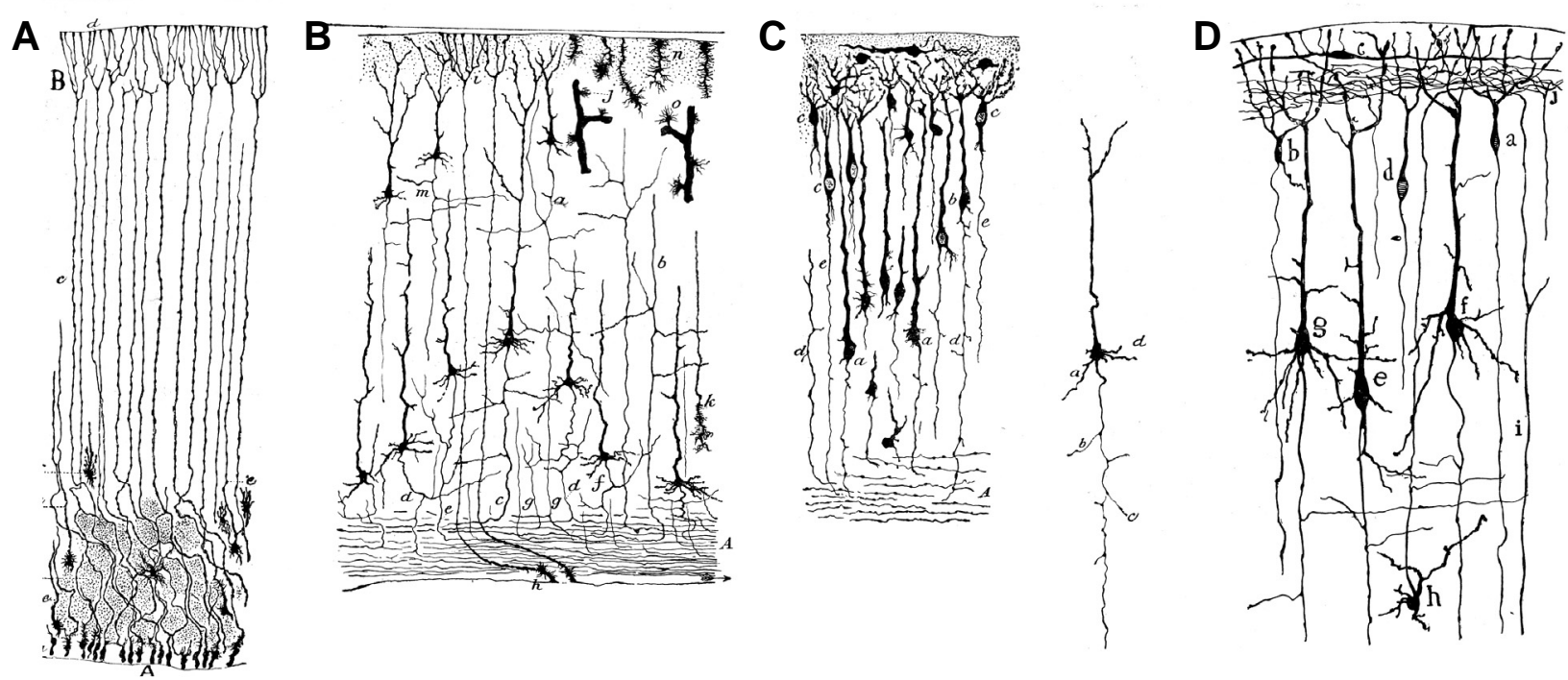

Fig. 11. Development of cortical pyramidal cells. (A) Golgi impregnated radial glia and differentiating astrocytes. The radial processes of these cells serve as guides for the migration of postmitotic pyramids towards the superficial cortical plate. (B,C,D) Various examples of immature pyramids. Note that the most mature elements lie deep, whereas the simpler and smaller elements are found superficially in the cortical plate. The most immature cells barely have a smooth apical dendritic process, starting to ramify in layer l. (C) Two migratory cortical neurons (near the white matter and midway through the cortical plate), showing a simple leading process and a trailing axon (typical migrating configuration). As the basal dendrites appear, the axon sprouts collateral branches. Cell " $h$ " in (D) apparently represents a deep cortical interneuron of the Martinotti cell type.

Purkinje cells as a more probable cause of such terminal selectivity.

Obviously the cerebellum, with its stereotyped repetitive structure in all vertebrates, was a favourable locus for visualizing such complex relationships. However, we must feel awed at Cajal's momentous insights in this domain, all achieved with a monocular microscope (Fig. 10) within the span of one year of intense work (1890), in coincidence with other equally important advances on other parts of the brain.

\section{Cerebral cortex}

Cajal contributed to our knowledge on developing cortical neurons as a part of his extensive studies on the telencephalic cortex in Man and small mammals (rabbit, mouse, rat, cat) (Ramon y Cajal, 1890f, 1891, 1893, 1894a,b, 1911, 1929; de Felipe and Jones, 1988). This includes observations on transient radial ependymal cells (radial glia, disappearing postnatally) as a probable source of free astroglia cells attached to blood vessels (Fig. 11, first two pannels).

Immature cortical pyramidal neurons (mouse) are mostly in place within the outer region of the cortical plate around E18. They distinctly lack basal dendrites and axonal collaterals, though their apical dendrite is fully developed and ends in layer I with a characteristic terminal bouquet. Other dendritic branches are barely present as short lateral or descending spikes. In Fig. 11 (third pannel), we observe that Cajal drew a migratory radial neuroblast that is just entering the inner part of the cortical plate, with a short unramified leading process and a trailing axon. Another migratory neuroblast appears already halfway across the cortical plate. Although he does not comment on these cells in the text, it is possible that he already conceived the inside-out postmigratory layering of young pyramidal neurons in the cortex. At P0, large deep pyramids already show a set of basal dendrites, and their local axonal collaterals are also well visible, though these will elongate and mature significantly during the first postnatal week (Fig. 11, last pannel). Dendritic spines appear later, and their presence implies for Cajal an indication of functional maturity of these neurons.

Another aspect of the developing cortex that attracted Cajal's attention was the structure of layer I. He noted that most fibers in this layer are unmyelinated even in the adult. Successful Golgi impregnations often showed many thin fibers coursing horizontally, mostly longitudinally (mouse, rat, rabbit). While some of these fibers probably are afferent (ascending from deeper layers), others seem intrinsic and arise from local neurons, whose typology he first described in detail. He distinguished small local axon neurons from larger "elongate or special cells"; the latter were also reexamined
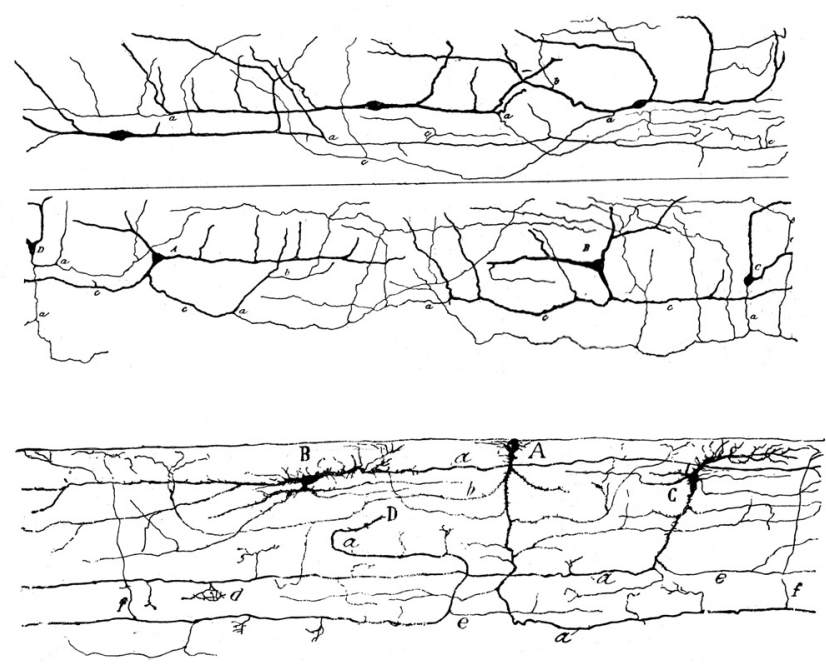

Fig. 12. Stages in the maturation of Cajal-Retzius. Note circumferentially disposed neurons of layer I in man. See description in the text. 
A

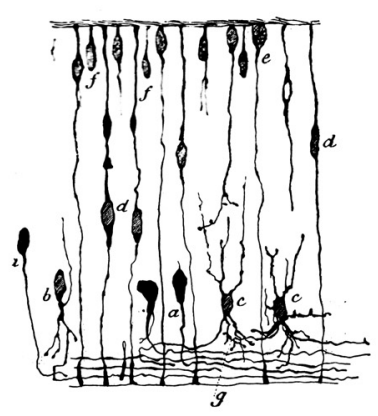

B

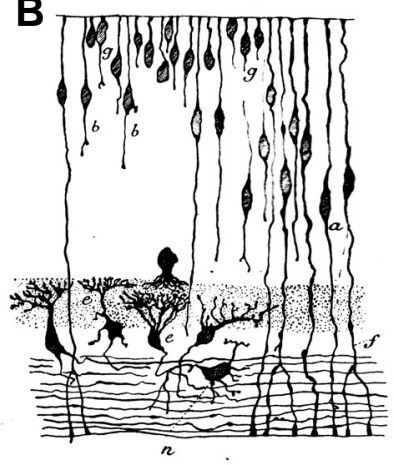

C

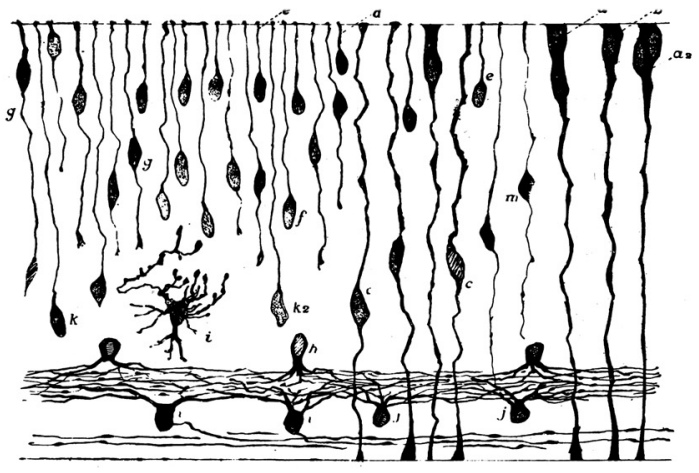

Fig. 13. Golgi observations on the developing retina. (A) Neuroepithelial cells (progenitors) and various stages in the differentiation of ganglion cells. Note the axons coursing away in the optic fiber layer. The most immature-looking cells lack dendrites, and such processes appear eventually in excess, directed both inwardly and outwardly. (B) A more advanced stage, in which most dendritic branches are now oriented to the incipient internal plexiform layer lone amacrine neuron is shown as well. Some of the neuroepithelial cells may be immature Müller glia cells (particularly those with bifurcated vitreal endings and cell bodies translocated inwardly). (C) Ganglion cells are contrasted with amacrines (including two inverted amacrines at right). There is one stellate cell with an incipient axon that Cajal interpreted as an immature horizontal cell (cell " $i$ "). The smaller cells contacting the outer limiting surface (ventricular lining) are immature photoreceptor cells.

in detail as "Cajal cells" by Retzius (1893), and they subsequently became known as "Cajal-Retzius neurons". The presence of scattered layer I stellate cells was a well known fact among histologists since Meynert's (1872) studies, but the detailed neuronal shapes were unknown, and some influential authors including Golgi and Edinger had postulated a possible glial nature of the layer I elements. The larger elongate or special elements are observed selectively in sections oriented longitudinally and are less abundant in small mammals than in Man. After Golgi impregnation they appear as smooth fusiform or triangular neurons with very long longitudinal dendrites, which finally ascend to end at the brain surface (Fig. 12). A very long circumferentially coursing and profusely branching axon originates from one of the dendritic ends. Along their course, the main dendrites emit collateral dendritic branches that in most cases also ascend radially towards the brain surface. Triangular cell shapes illustrated by Cajal seem to the present author to result from progressive translocation of the somata into one of the ascending dendritic branches, with subsequent formation of additional obliquely ascending main dendrites (Fig. 12; Ramon y Cajal, 1929). Embryonic forms of these cells were first reported by Retzius (1893) in the human and his data were later completed by Cajal as regards the postnatal period (Ramon y Cajal, 1911). No one imagined at the time that CajalRetzius neurons and most cortical interneurons respectively originate from extreme pallial areas (i.e., cortical hem) or from extracortical subpallial sources, and migrate tangentially into the cortical primordium early on in development, as we now know, 100 years later.

\section{Retina}

Using among other resources an ingenious method for efficient production of Golgi impregnated retinas (carefully rolling up the unfixed retina like a carpet and protecting this roll under a celloidin coat; see footnote in page 255 of Ramon y Cajal, 1929), and, later, his neurofibrillary method, Cajal addressed the neuronal structure of the vertebrate retina, as well as the development of its cell types in the chicken, owl, mouse, rabbit, cat, dog, and cow (Ramon y Cajal, 1888a,b, 1889f, 1893b, 1894b, 1896, 1904c,d, 1906, 1908, $1911,1919,1929)$. His autobiography indicates as well some early observations on the retina of teleosts, frogs and reptiles. We will not refer here to his parallel work on the retina of invertebrates (with D.Sánchez).

Cajal's embryonic Golgi observations on the retina started to succeed at embryonic stages approximately just before the formation of the inner plexiform layer (Fig. 13; Ramon y Cajal, $1888 \mathrm{a}, \mathrm{b}, 1889 \mathrm{f}, 1893 \mathrm{~b})$. He noted that immature ganglion and amacrine cells can be impregnated at the inner aspect of the retina at about the same time, jointly with ventricular cells (interpreted as immature Muller cells). The two cited neuronal types subsequently differentiate as the plexiform layer forms. He commented on the general histologic similarity of the retinal neuroepithelium and early retinal neurogenetic phenomena with the features of the developing spinal cord.

The most immature ganglion cells he saw had a smooth piriform soma and an already elongated axon (Fig. 13). He did not succeed in impregnating younger forms with visible growth cones, possibly due to excessive hardening of the delicate material by osmic acid. Such forms were eventually extensively illustrated by Prada et al. (1981) in the chick, using an osmic-acid-free Golgi variant, the Golgi-Stensaas method (Fig. 14, bottom). The ganglion cells later sprout transient outer and inner dendritic branches (Fig. 13 A,B). Plastic interaction with bipolar and amacrine afferents leads to selective growth of the outer dendritic tree, inserted in the inner plexiform layer, and retraction of previous transient inner processes. Curiously, at the time it was still being discussed whether the optic nerve develops from the retina towards the brain or viceversa. Cajal's parallel obervations on the chick optic lobe convinced him that the optic tract largely ends with terminal arborizations in its central targets, but he did not negate the presence of a contingent of centrifugal fibers (indeed, birds have a sizeable isthmo-optic tract ending in the inner retina; this component seems less important in mammals).

Apart other interesting Golgi observations on developing bipolar, horizontal and photoreceptor cells (Ramon y Cajal, 1893b, 1929), Cajal reflected on the remarkable specificity in the establishment of cell-to-cell contacts in the retina, and the various evidence of perikaryal translocations, suggesting that both mechanical and chemotactic mechanisms guide selective "ameboid" 
movements of the cell bodies and processes -particularly of horizontal cells- until they attain a definitive arrangement (Ramon y Cajal, 1893b, 1929). A footnote in page 253 of the 1929 book reveals that Cajal later had second thoughts and considered that this early chemotactic hypothesis of his might be too risky. Nevertheless, that early insight actually preceded by 100 years our present emphasis on highly discriminative intercellular molecular communication, growth guidance and control of differentiation and migration, though the details of molecular signals underpining retinal circuitry formation remain still very much under study. Cajal did not succeed in impregnating migrating amacrine cells, again probably because of the osmic acid in his fixative solution. Prada etal. (1987) found with the Golgi-Stensaas variant two sorts of presumptive amacrine cells, calling them
A

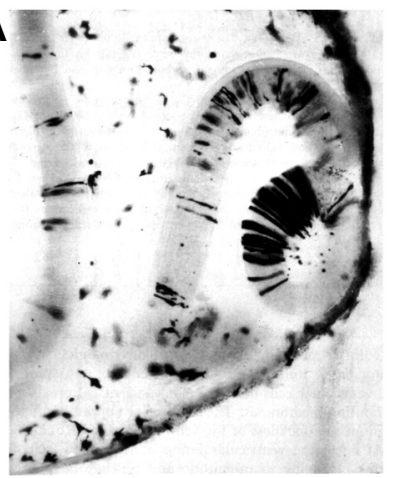

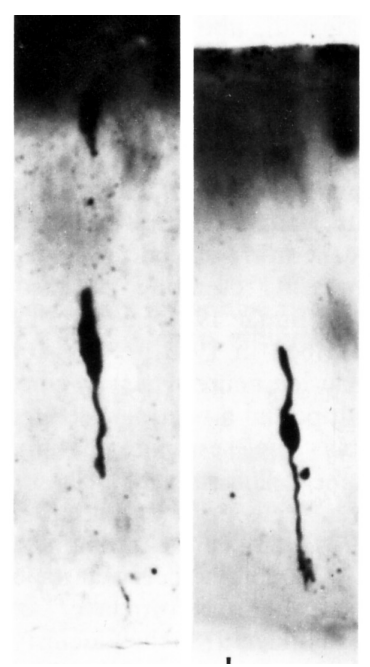

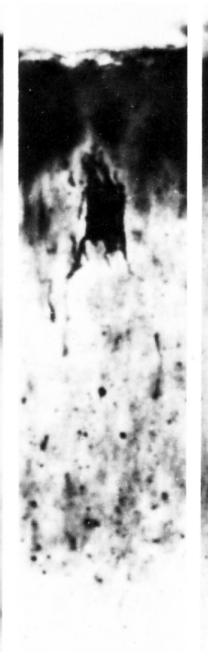

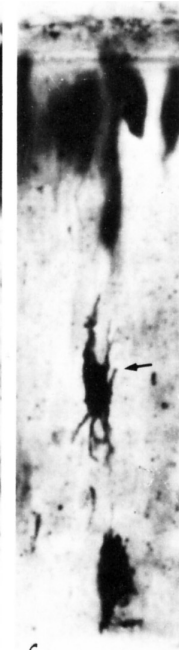
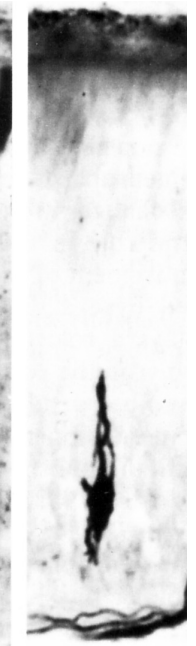

Fig. 15. Migrating immature amacrine cells. Bipolar and multipodial forms of presumptive amacrine cells (possibly including also immature horizontal cells) as described with the Golgi-Stensaas method in the chick by Prada et al. (1987). Compare the multipodial shapes with the immature forms of horizontal cells detected by Cajal (Figs. 13C, 16).

"bipolar" and "multipodial" cells; the latter were postulated also as a possible source for horizontal cells (Fig. 15), a point of view recently supported by Edqvist and Halböök (2004).

In a second effort (Ramon y Cajal, 1906, 1908, 1911, 1929), Cajal communicated that immature cones of the retina could be distinguished from immature rods by their larger amount of somatic cytoplasm (darker versus paler appearance after impregnation). Photoreceptors pass sequentially through unipolar, bipolar and adult shapes. While the earliest postmitotic phases of differentiation of horizontal cells resisted efforts to impregnate them, later young forms, characterized by a transient overgrowth of sclerad and vitread dendritic branches and an incipient varicous axon, allowed to distinguish outer and inner horizontal cells, having respectively thin or thick axonal endings. Subsequent stages of horizontal cell maturation were also described, leading to the novel finding that horizontal cells are retinal interneurons whose axons finish within the outer plexiform layer (the Russian author Dogiel had affirmed that they send their axons into the optic nerve). Bipolar cells could be identified only in older specimens, corresponding to our present knowledge that they are among the last retinal cell types to be produced. Cajal distinguished morphologically the rod and cone bipolar cells. He also identified inverted amacrine cells among the elements populating the ganglion cell layer (Fig. 13C, Ramon y Cajal, 1909). Inverted retinal cell types (subtypes of amacrine and ganglion cells) are produced because early-born neurons such as these presumably aggregate initially at the prospective radial locus of the inner plexiform layer. During the subsequent rapid development of this plexiform layer, containing terminal dendritic arborizations of ganglion and amacrine neurons plus the terminal axonal arborizations of bipolar cells, some outlying neurons of either type become transiently caught in an intraplexiform position. Soon afterwards these intraplexiform elements translocate their somata to the nearest layer (either the inner nuclear layer or the ganglion cell layer), and differentiate according to their type; some translocate into the wrong layer and
Fig. 14. Early developing cells of the chicken retina. (A) Crosssectioned early chicken retinas. The specimen on the left was Golgiimpregnated at E2.5 with the Golgi-Stensaas variant by Prada et al (1981), showing proliferating retina progenitors and immature lens cells starting to differentiate. On the right, E4 chick retina silver-stained by Cajal, showing the early formation of the retinal papilla and the optic nerve by axons from the differentiating ganglion cells. (B) The sequence of ganglion cell differentiation as observed with the neurofibrillar method. (C) Examples of very immature ganglion cells, starting to produce their axon, impregnated with the Golgi-Stensaas variant by Prada et al. (1981). Cajal's rapid Golgi method with osmium failed at obtaining these forms. 
these are the "inverted" elements (Genis-Galvez et al., 1977).

The development of retinal horizontal cells was investigated again later in newborn and fetal mice, using the pyridine-silver nitrate method (Ramon y Cajal, 1919a, 1929). Cajal could not detect transitional forms between "germinal cells" and immature horizontal cells. He nevertheless distinguished for these neurons an initial monopolar/bipolar phase, followed by stellate, horizontal and final "modelling" phases. The monopolar/bipolar cells identified as earliest prospective horizontal cells (Fig. 16A) typically show a cell nucleus larger than that of surrounding bipolar and amacrine cells; they appear distributed at various distances from the inner plexiform layer (the outer plexiform layer being still absent at this stage; see also cell labeled "i" in Fig. 13C, which has an axon). The apparent absence of younger forms closer to the germinal cells and the radially distributed topography that diminishes postnatally were for Cajal consistent with the idea that the horizontal cells derive from amacrine cells, or at least share with amacrines an early phase of postmitotic life at the inner aspect of the retina, before aggregating at their definitive more external locus. We have recent data indicating the existence of a common progenitor for amacrine and horizontal cells (Li et al., 2004; Fujitani et al., 2006). Such immature forms are compatible with the "multipodial" ameboid immature amacrine cells identified by Prada et al. (1987). In other words, prospective horizontal cells possibly select their fate while mixed with amacrine cells at the inner part of the retina and would migrate outwards across the inner nuclear layer, approaching the incipient outer plexiform layer (many of Cajal's images are consistent with this interpretation; compare Figs. 15 and 16A). Cajal did not state forcefully this hypothesis, but he did say textually:

"... it would seem that, owing to their ameboid movements and

A
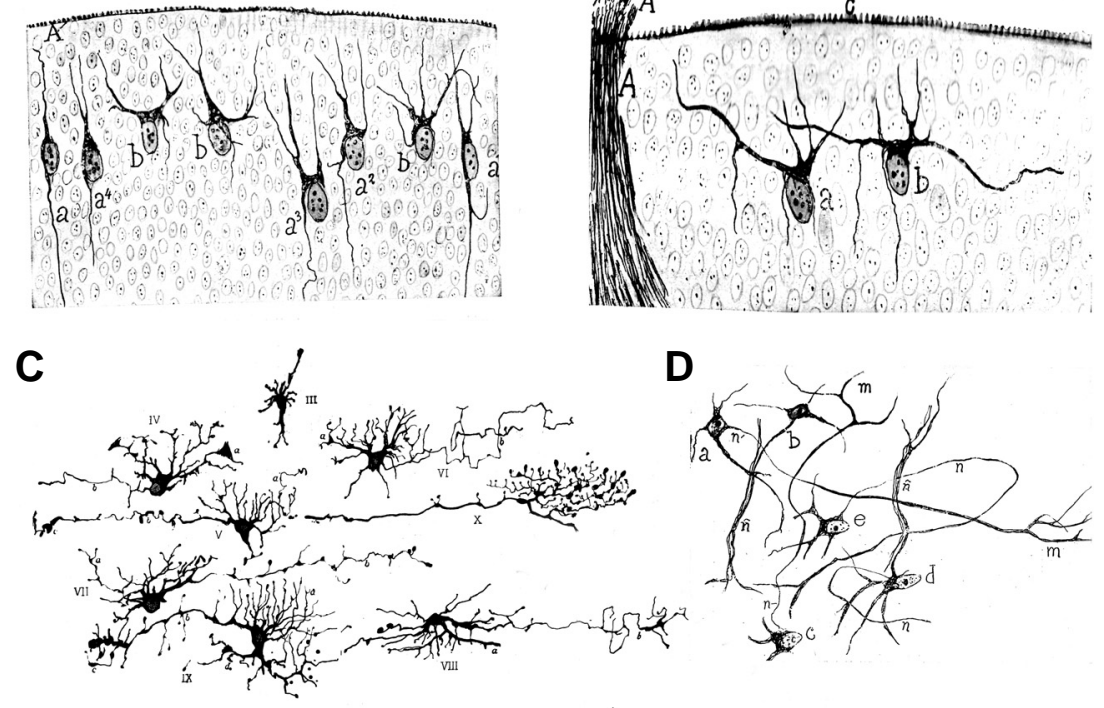

Fig. 16. Differentiation of horizontal cells of the retina. The most immature bipolar forms of the horizontal cells change into multipolar shapes as they aggregate in contact with the incipient outer plexiform layer. Transient inner processes are lost gradually. Sections of flat-mounted retinas (bottom pannels) allow to see the growth of the horizontal cell axons, as well as the developing dendritic trees. The axons finally develop a dense terminal "brush" (at " $X$ "). (C) Golgi-impregnated samples. (A,B,D) Silver-stained samples (note haphazardly bending courses of the axons).

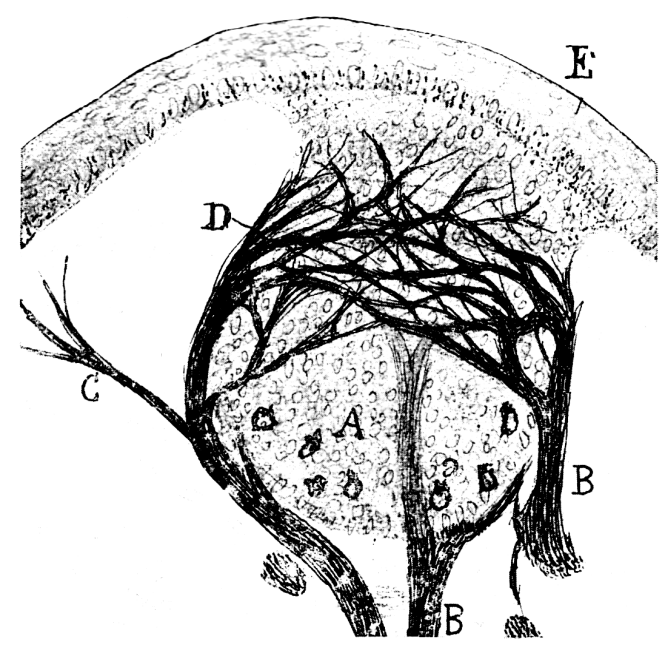

Fig. 17. Development of a dendritic plexus at the base of a hair primordium. Cajal thought this pattern reveals that the sensory dendrites are attracted chemotactically by the primordium, and are repelled by the normal skin.

to attractive influences of enigmatic origin, these [immature horizontal] cells have a tendency to aggregate more and more at the locus which they will occupy later" (Ramon y Cajal, 1929, p.272). This insight has received strong support from recent experimental studies (e.g., Edqvist and Halböök, 2004).

The outer pole of these cells is always more massive than the inner one, which eventually disappears. Cajal comments on an apparent fibrillogenic center in this part of the cytoplasm, analogous to that observed previously by him and Held in young spinal cord neurons. He thinks that neurofibrils elongate out of this center into the cell processes by propagative (infectious) expansion of a population of "neurobiones", defined as the "ultramicroscopic units of the neurofibrils". This astounding concept obviously predates by many years the modern molecular and electron-microscopic concept of neurofibrilar protein units polimerizing (or depolimerizing) linearly under central control of the centrosome. Around birth, the monopolar immature forms of horizontal cells transform into stellate cells with multiple and divergent cytoplasmic expansions. The cells now display several ascending dendrites, as well as some horizontal or oblique ones (Fig. 16B). Some cells have one or two thin inner processes, which Cajal apparently interprets either as remnants of the previous ameboid outward migration or as novel outgrowths, i.e., as an incipient axon without a visible growth cone (let's remember that the neurofibrillar method does not show well the growth cones). An axon often cannot be identified with certainty at these early stages due to their very variable spatial orientation, making them often fall out of the sections. Tangential sections of the retina do show a longer process that clearly is the axon, finishing when mature in a peculiar bushy terminal (various stages of horizontal axon elongation and matura- 
A
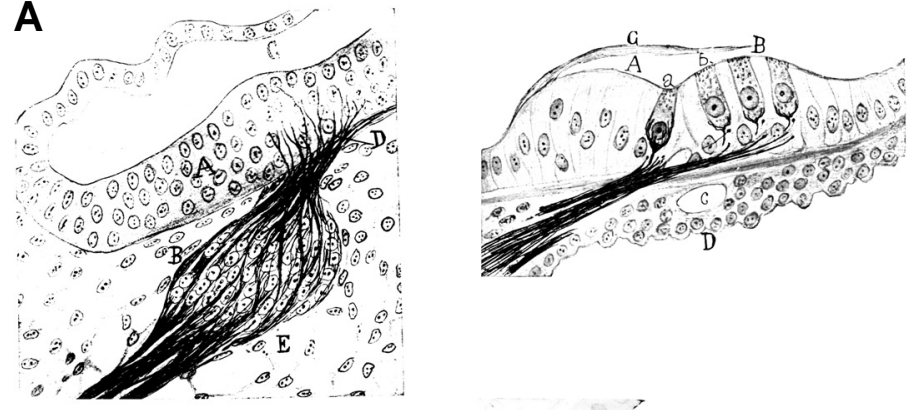

B

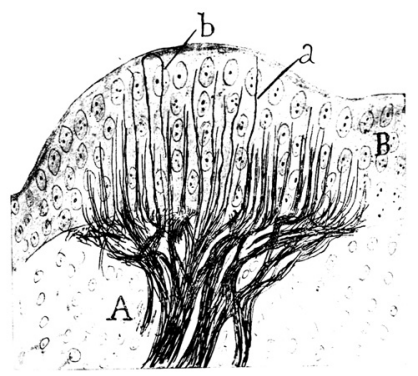

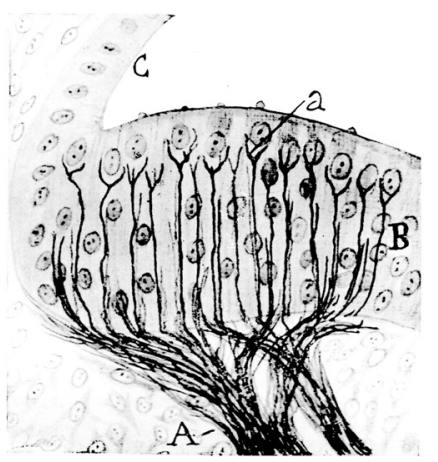

Fig. 18. Silver-stained sensory innervation of the cochlear and vestibular organs. Drawings of the cochlea (A) and of a vestibular ampullary organ (B) illustrated at two stages. In both cases, initial penetration of sensory dendrites at a specific locus (chemotaxis) is shown at left, folowed later by secondary differentiation of contacts with the specialized placodal receptor neurons (at right).

tion are represented in Fig. 16, bottom, taken from such sections). However, a subtype of horizontal cell remains axonless.

Between P2 and P8 in the mouse, there is a substantial development of the outer dendritic branches and progressive restriction of cell bodies of horizontal cells to the neighborhood of the prospective outer plexiforn layer (this forms in the mouse between P12-P18, according to Cajal). This leads to the horizontal phase of the differentiation sequence. Some horizontal neurons continue having arciform axonal processes that first course inwards and then trace a curve coming back to the outer plexiform layer. Once the outer plexiform layer starts to form after P12, the horizontal cells increasingly reabsorb or retract the radially oriented inner cell processes and develop an extensive tangential set of much ramified dendritic branches, with secondary outer radial terminals that contact the photoreceptor axonal formations. Growth-cone-like distal expansions of the axons become clearly visible; the axons frequently depart from the initial straight course, doing aleatory roundabouts in the tangential plane, which were suggestive to Cajal of a lack of guidance (Fig. 16D). By P25 a nearly adult configuration of horizontal cells is achieved (phase of final modelling).

The same report (Ramon y Cajal, 1919a, reproduced in 1929) contains at the end highly significant general considerations, where Cajal makes a far-reaching synthesis of his findings on the differentiation sequence of neurons. None of them seem out of place in a modern textbook. A main conclusion is that, similarly to projection neurons, immature short-axon neurons transiently show a bipolar fusiform and radially oriented shape. He thinks this stereotropism results from interplay between an intrinsic tendency to form expansions and mechanic adaptation to the sur-

rounding, radially organized neuroepithelium (" the transversal pressure of neighboring corpuscles"). Some or all of the cytoplasmic processes formed during this phase may be transient. The large variety of immature cell forms observed suggest that neurons have considerable freedom of movement and "... transform themselves as a leucocyte that adventures through a complicated texture full of obstacles". Importantly, since horizontal cells first occupy several levels of the retina and later aggregate at a single level, it must be admitted that neuroblastic ameboidism is real. The machinery forming cell processes relates to the Golgi apparatus and the centrosome. This is first concentrated at one end of the soma (bipolar/monopolar phases) and later expands perinuclearly (allowing cell processes to appear all around the soma) (Ramon y Cajal, 1912a, 1914b, 1915, 1929).

Initial aberrant courses of axons and dendrites are said to be due to relative absence of chemotactic sources at early stages of development (Cajal, 1919a, 1929). There exist "exploratory (pioneering) fibres", to which those formed subsequently adhere, forming dendritic or axonal bundles ("reciprocal chemotactism"). Neurotropic sources (neurotropism being qualified in a footnote as a working hypothesis) appear relatively late in the retina. Cajal thinks this concept is needed in order to explain the transition between the disoriented early stage of differentiation and the fully aligned subsequent configuration. Final modelling of the cell types occurs as a response to these unknown signals. During the formation of the outer plexiform layer, he tentatively identifies the axonal terminals of the differentiating photoreceptors as the main local sources of neurotropic signals for the horizontal cells, though he does not discount
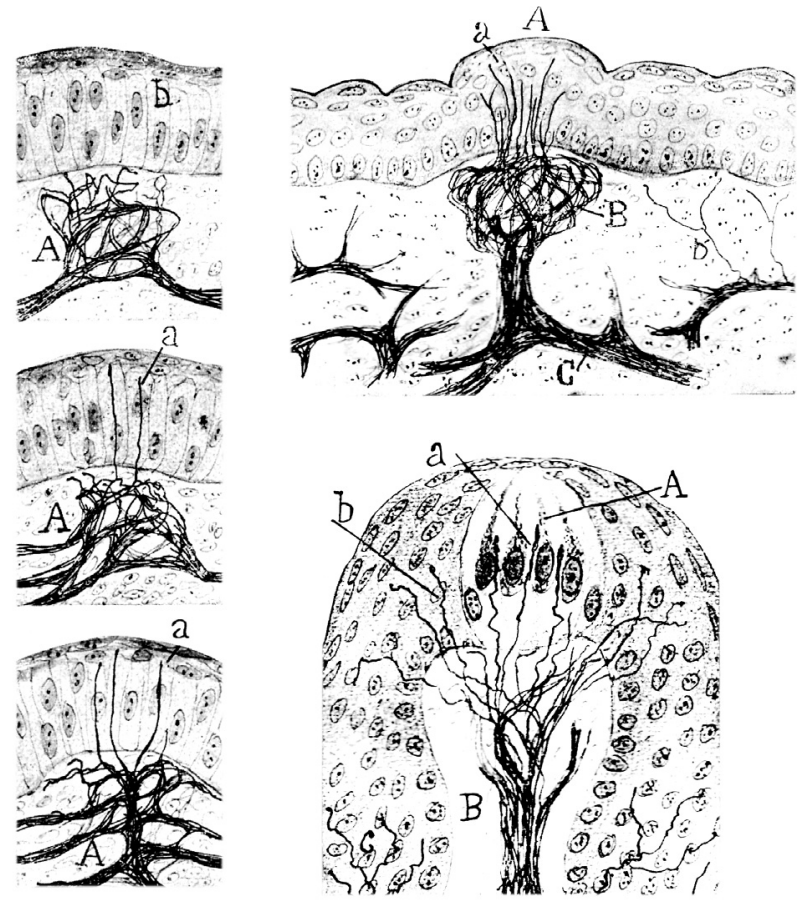

Fig. 19. Sequence in the dendritic innervation of a gustative papilla. The terminals first form a sharply localized plexus before the papilla specialization is visible histologically. In subsequent steps, terminals start to sprout from that plexus and penetrate radially the papilla, in increasing numbers. Finally, the sensory cells differentiate and are contacted by the terminals. 
a possible additional role of the dendritic bouquets of the rod bipolar cells. Cajal regarded the transient arciform courses of aberrant horizontal dendritic branches and axons as further evidence of neurotropic influences acting upon receptive cell processes which had initiated a "wrong" course, but are able to respond to signals by reorienting their growth.

Finally, he concluded that survival of cell processes and eventually of the somata depends on making correct connections (Cajal, 1919a, 1929). Aberrant or lost processes that do not reach their predetermined targets within 15 days ("unuseful appendices") are destined to atrophy by reabsorption (terminal corrosion or autotomy). Loss of the entire axon probably entails degeneration of the parent cell body. He concluded that cell death is therefore a normal event in the developing brain. The frequent transient stage in neuronal differentiation in which an excess of dendritic branches is displayed may be a natural way to increase the probability of the needed connections. Cajal (1919a, 1929) even speculates that germinal cells and neuroblasts may be also overproduced with the same probabilistic effect, though he lacked data at the time to support this now firmly established idea (Haydar et al., 1999; Kuan et al., 2000; Brown et al., 2001; Sanes et al., 2002). As a consequence of all this, he postulated that during neurogenesis there is competition between dendritic and axonal processes (and therefore among neurons) for available space and nutrition (trophic factors). The cells and processes that are initially best placed with respect to sources of nutrition and neurotropic signals, as well as to neighboring neurons with which they need to establish dynamic interactions, will eventually "triumph" in this fight. He nevertheless cautions against exagerating the extent and importance of neural competition, in analogy to "rigorous darwinian selection admitted for organisms" (compare Edelman, 1987). He speculated that probably the majority of neuroblasts achieve functional equilibrium in the mature neural centers. Cajal separated the cases studied in neuropathology and psychiatry, in which mechanic or pathologic agents intervening during embryonic development may partially distort or blunt the histogenetic progress of the nervous system.

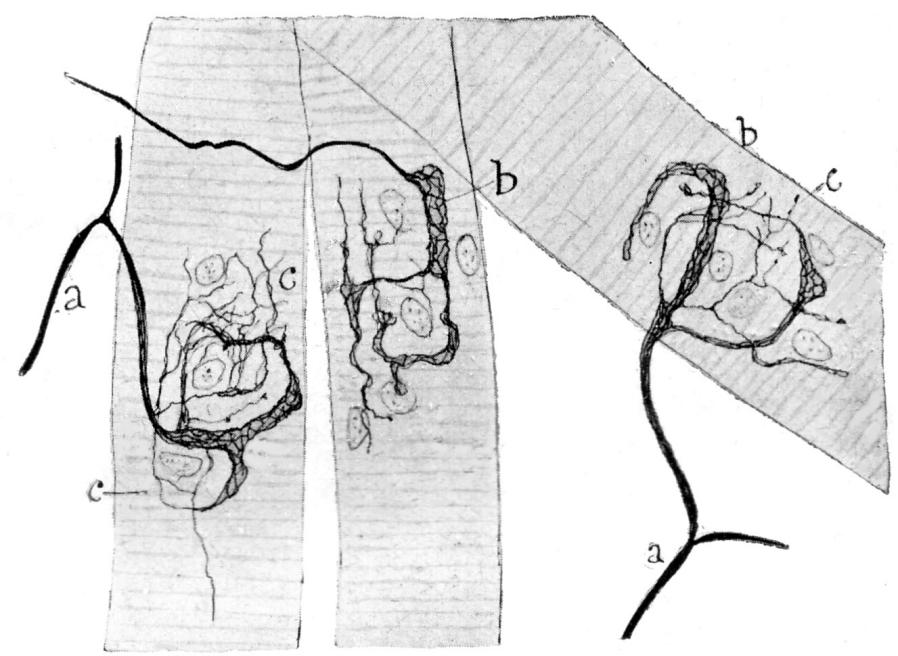

Fig. 20. Neuromotor innervation. Early stage in the innervation of muscle fibers by a motoneuron axon terminal.
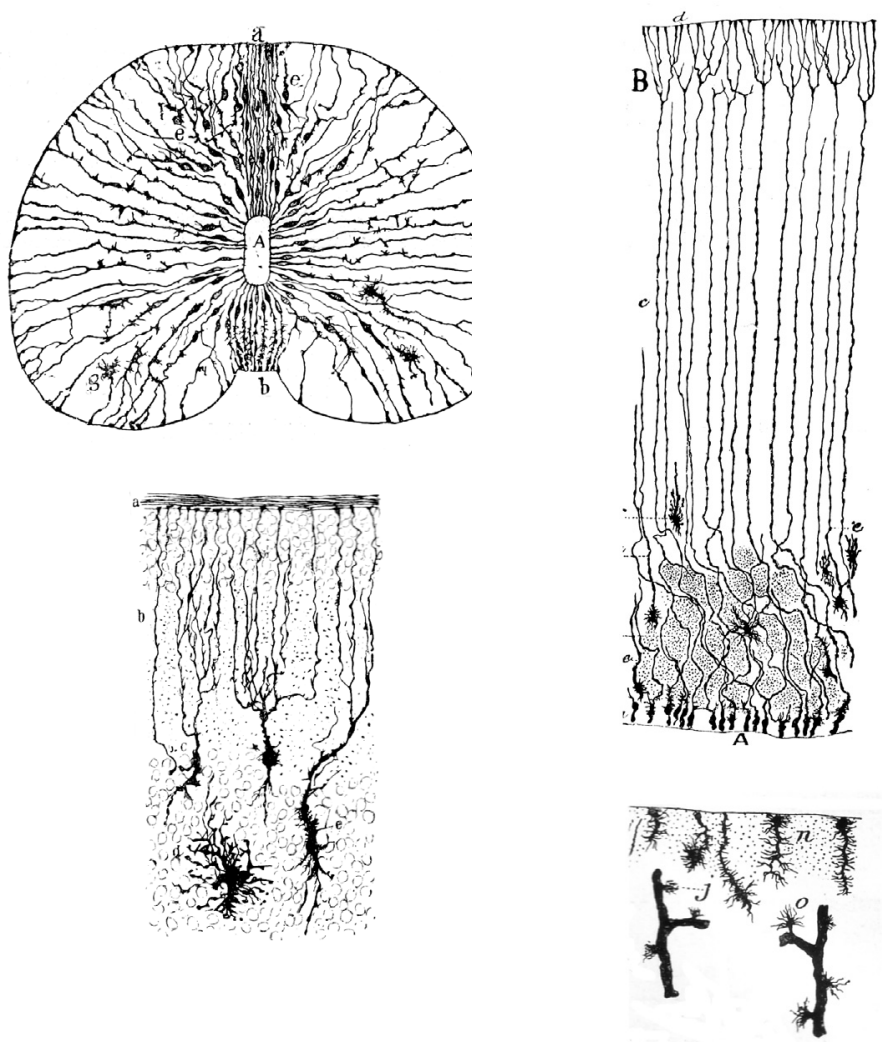

Fig. 21. Examples of differentiating astroglia, after Golgi impregnation. At the top, E9 chick spinal cord. Note specialized shapes of radial glia at the roofplate and floorplate, and some free astrocytes of the ventral horns. The second pannel shows Bergmann astroglia of the cerebellar cortex. They have multiple pial processes traversing the molecular layer and the cell bodies translocate outwards, stabilizing roughly at the level of Purkinje cells. The last two pannels show cortical astroglia. The immature forms are radial glia and free astroglia with long pial processes. The bodies gradually translocate outwards, approaching eventually the pia (last pannel). Note vascular endothelial growth buds that Cajal confused with forms of astroglia (his spider cells).

\section{Sensory and motor terminal structures}

A further developmental domain visited by Cajal was the development of sensory and motor terminals in birds and small mammals, in connection with the neurotropic hypothesis (Ramon y Cajal, 1904e; 1919b; 1920; 1925; 1929). There were also significant publications on this topic from Tello (Tello, 1906, 1917). In order to provide more specific content to the neurotropic hypothesis, Cajal $(1910 ; 1919 b)$ conjectured that the nature of the chemical interaction occurring between neurotropic source material and the neuronal membrane might be of enzymatic character or analogous to the antigen-antibody reaction studied in bacteriology.

Cajal studied formation of intraepithelial sensory terminals in the cornea, skin of the breast, muzzle, lips and eyelids, tactile bristles (Fig. 17), as well as sensory terminals in the cochlear and vestibular organs (Fig. 18) and the gustatory buds (Fig. 19) and other sensory specializations of the tongue. In every case he noticed constant details of temporal and topographic distribution of growing dendritic buds that necessarily bespeak of the agency of spatially-stereotyped neurotropic sources that attract or repel (negative chemotaxis) the fibers in various phases 

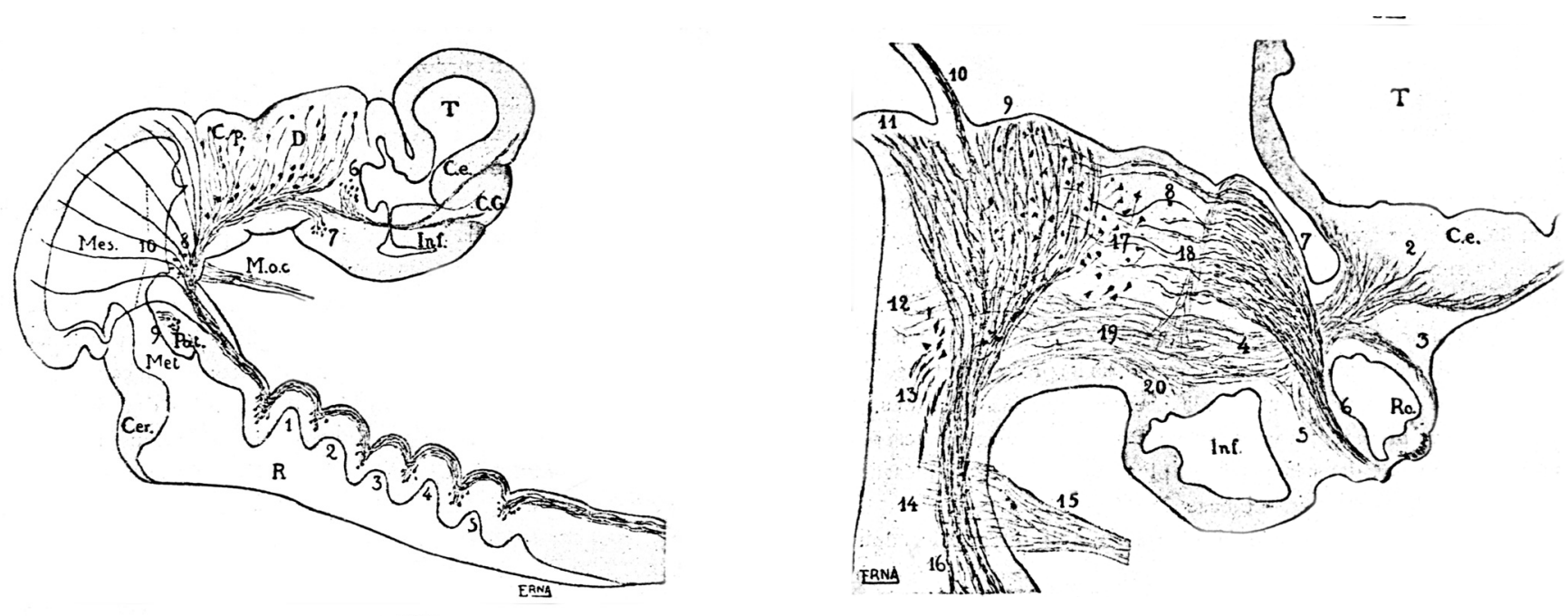

Fig. 22. Neuromeric conception in Tello (1923). Figures 22 and 37 of the report on neurofibrillar differentiation in the chick brain are reproduced here. The one above (his Fig.22; 3 days of incubation) represents a schema of observed early fiber tracts relative to segmental neuromeric subdivisions. Note 5 rhombomeres, corresponding to present-day rh2-rh6, whereas rh1 and the isthmus are encompassed within the metencephalon (Met). The trochlear (pathetic) nerve nucleus lies in the isthmus (Pat). The C.p. tag marks the pretectum, which appears delimited by dorsal and ventral surface furrows from the midbrain tectum and the thalamus (tagged D; these furrows are partly artefactual, due to fixation in pyridine). The thalamus also appears separated by surface furrows from the prethalamus (containing cell group labeled 6 ), and this contacts rostrally the secondary prosencephalon (hypothalamus and telencephalon). In his text, Tello explicitly holds the fibers extending into the supraoptic commissures (between Inf and C.G.) as indicating the rostral end of the longitudinal dimension, whereas the telencephalon lies "upwards" (dorsalward). This conception agrees remarkably with the prosomeric model. The second drawing (his Fig. 37; 5 days of incubation) shows a sagittal section through the diencephalon and secondary prosencephalon, highlighting the orthogonality of the diverse fiber tracts. Note the neuromeric units prethalamus, thalamus and pretectum, correlative to numbers 7, 8 and 9, respectively, as well as the oculomotor nerve (15), interstitial nucleus of Cajal and medial longitudinal tract (12, 13), tectotegmental fibers (11), posterior commissure fibers (9), and the longitudinally coursing optic tract, just reaching the thalamus. The diencephalic zona limitans is identified by ostension for the first time in neuroembryological literature 118; it was described in more detail again by Rendahl, 1924, one year later, who passes as its discoverer). The peduncular fibers course longitudinally through the diencephalic basal plate (19) and bend into a ventrodorsal trajectory (4) as they enter the hypothalamus at the level of the prospective subthalamic nucleus, thus crossing orthogonally the optic tract and supraoptic commissures.

to their definitive functional distribution. General conclusions treated at the end of this beautifully illustrated report (Ramon y Cajal, 1919b; 1929) again allow the master to exert his commonsensical vein in insightful synthetic thinking. A subsequent paper connected the issue of regenerating nerves to that of sensory and motor fibres innervating muscle (Fig. 20), or growing outside the brain, in connection with the accessory role of Schwann cells, which he wrongly interpreted as being of mesodermal origin (Ramon y Cajal, 1920; now we know they are neural crest derived); many of the ideas referred to can be found as well in his earlier treatise on neural degeneration and regeneration (Ramon y Cajal, 1913, 1914).

\section{Astroglia}

As regards astroglia, Cajal first described in the spinal cord the early gradual translocation of the cell bodies of radial glia into the mantle layer, a change occuring earlier in the anterior horn than in the posterior one (Fig. 21, upmost pannel). Astroglial translocation implies that primary radial glial cells attached by desmosomes at the ventricular lining and characterized by radial processes ending in pial endfeet lose their ventricular attachment site, while keeping the subpial endfeet, and their cell bodies subsequently sort out of the ventricular zone by somatic translocation and adopt a more superficial position. Similar forms of immature astroglia attached to the pia can be found in the cerebellum (Bergmann glia; Fig. 21, second pannel), or the cerebral cortex (Fig. 21, third pannel). Gradual shortening of the pial process leads to the formation of free astrocytes, which remain attached either to the pia or, once vascular ingrowth occurs, to the wall of blood vessels (the latter is also covered by mesodermal pial tissue; Ramon y Cajal, 1890a). Cajal noted that some of these cells possess two nuclei and therefore agreed with other authors that they might be able to divide. Curiously, Cajal also considered the possibility to regard free astroglia as non ectodermal cells associated to blood vessels (he calls these "spider cells", due to the radiating thin filopodia they display). $\mathrm{He}$ conjectured they might originate from vascular endotelial cells or from connective tissue cells associated to the wall of capillaries (Ramon y Cajal, 1929; p.221). The evidence he offered for this wrong idea apparently involves misinterpreting as immature astroglia the endothelial growth buds of cerebral blood vessels, which have characteristic radiating filopodia; their aspect after Golgi impregnation is indeed very similar (see Fig. 21, bottom pannel, taken from Ramon y Cajal, 1929, chapter XI, Fig. 2; the cells associated to the pia are free astrocytes, but the supposedly glial elements depicted upon the blood vessels are vascular growth buds). However, Cajal clearly expressed reserves on this conclusion in the original legend of this Figure, as well as in a footnote added in 1929, where he correctly postulated the immature vascular glia to have also an ectodermal origin (Ramon y Cajal, 1929, p.223). It is not clear whether Cajal ever recognized the vascular "spider cells" as being endothelial growth buds. 
Bergmann glial cells of the cerebellum, peculiar because they develop multiple pial processes, also were found to differentiate and become positioned close to Purkinje neurons following a similar translocating process (Fig. 21, second pannel; Ramon y Cajal, 1890a). Retinal Müller cells constitute another special astroglia form that translocates its cell body into the internal nuclear layer of the retina and matures while retaining both the pial and ventricular attachments.

\section{Epilogue: neuroembryological contributions of J.F.Tello}

Jorge Francisco Tello was the preferred pupil of Cajal, the only in the cajalian school that can be properly regarded according to his interests as a neuroembryologist. He was Cajal's assistant at the histology-pathology department of the Medical School in Madrid, succeeding him later in this chair. A highly capable, plurifacetic personality, for many years he was also deeply involved in bacteriology, vaccination campaigns and public health, in which field he reputedly was a major expert, with frequent official missions to disease-hit areas of Spain. These other activities caused silent intervals between his publications. He nevertheless demonstrated over the years a long-standing dedication to neuroembryology, which increased when he took over from the master the administration of the Cajal Institute. He replaced him as its director after his death (in 1934). He singlehandedly saved the histological and bibliographic heritage of the Cajal Institute from destruction during the Spanish civil war (19361939), but in the aftermath was demoted from the direction of the institute and also from his university chair for political reasons. He nevertheless continued publishing up to his death in 1958.

Tello did numerous studies on the development of sensory and motor peripheral terminals, the neural crest, and sympathetic and sensory ganglia. He also tested experimentally the neurotropic hypothesis of Cajal and did work on neural degeneration and regeneration. He also published a number of important reports dealing with early neurogenesis and neurofibrillar differentiation patterns in various parts of the brain, which still merit perusing: there was first a large monograph covering the chick brain, published in Spanish and French (Tello, 1922, 1923), and then, turning to the albino mouse, developmental studies on its forebrain (Tello, 1934a), mammillary bodies (Tello, 1934b; 1936/ 1937), cerebral cortex and fornix tract (Tello, 1935, 1936), and cerebellum (Tello, 1938). In his own words, his "histogenetic motivation was to know how the different neural centers appear and acquire their characteristic structure during development, aiming to find indications of how these formations are stimulated".

One remarkable aspect of Tello's (1922, 1923, 1934a) neurofibrillar studies of the chick brain and mouse forebrain is his systematic use of neuromeric subdivisions in his descriptions. This is in contrast with Cajal's and His' lack of use of this morphological concept. However, Tello did not give his rationale for doing so, nor justified in any way his particular neuromeric schema. Tello counts in the hindbrain only five rhombomeres (15 ), corresponding to the well-delimited ones (rh2-rh6 in modern nomenclature). He places correctly the trochlear nucleus in the isthmus, and recognizes the intervals in the attachment of mixed cranial nerve roots to alternate rhombomeres (the paired ones in modern use). He is less specific about the number of neuromeres in the diencephalon, but his accurate drawings from chick em- bryos at 3 and 5 days of incubation (Fig. 22; Tello, 1922, 1923), as well as his interpretation of microphotographs of embryonic mouse forebrain in sagittal sections (Tello, 1934a; see his Fig. 4), reveal a tripartite schema (Fig. 22; pretectum, thalamus and prethalamus); this leaves apart the rostrally placed hypothalamus, consistently with the modern prosomeric model (Puelles and Rubenstein, 2003; Puelles et al., 2007). He nevertheless seems to have counted the pretectum as a part of the midbrain, instead of as a caudal diencephalic unit, which is the modern trend supported by molecular specification data. Tello $(1922,1923)$ clearly considered axonal trajectories in the forebrain as aligned with either the orthogonal AP or DV dimensions of the neural tube and its neuromeres, an important interpretive possibility not available to users of the alternative columnar model (Fig. 22). Unfortunately, Tello did not comment at all on the origin of his advanced segmental thinking. Maybe he got acquainted with this neuromorphological paradigm during a 10 month stay he did in Berlin. It is thus possible that he may have based his neuromeric approach in von Kuppfer's (1906) monograph, or in the earlier work of Orr (1887), in which "neuromeres" were first named and defined histologically.

His paper on the cerebellum (Tello, 1938) contains a remarkable description of tracts entering and sorting out of the cerebellum, as well as pioneering tracings of distinct Purkinje cell groups migrating en masse with trailing axons into the expanding cerebellar cortex. He interpreted the secondary transformation of the Purkinje cell layer into an unicellular sheet as produced by intercalation of the deeper cells into the overlying cortical primordium, since he did not find evidence of the lateral shearing postulated by Cajal. Tello was a clear-headed master of neurofibrillar procedures and one wonders what may remain at the Cajal institute or elsewhere (medical school in Madrid's Complutense University) of the extraordinary collection of preparates he must have prepared over the years.

\section{Acknowledgments}

The expert help of $M^{a}$ Angeles Langa Langa, Chief Librarian at the Instituto Cajal, CSIC, Madrid, is most gratefully acknowledged. She corrected and completed the literature citations of Cajal mentioned in this report.

\section{References}

BROWN, M., KEYNES, R., and LUMSDEN, A. (2001) The Developing Brain. Oxford Univ.Press.

CEPKO, C.L., GOLDEN, J.A., SZELE, F., and LIN, J.C. (1997) Lineage analysis in the vertebrate central nervous system. In Molecular and Cellular Approaches to Neural Development(Eds. W.M.Cowan, T.M.Jessell, S.L.Zipursky). University Press, Oxford, pp. 391-439.

DE FELIPE, J. and JONES, E.G. (1988) Cajalon the Cerebral Cortex. An Annotated Translation of the Complete Writings. Oxford Univ.Press, New York, Oxford.

EDELMAN, G. (1987) Neural Darwinism: the theory of neuronal group selection, Basic Books, New York.

EDQVIST, P.-H.D. and HALLBÖÖK F. (2004) Newborn horizontal cells migrate bidirectionally across the neuroepithelium during retinal development. Development 131:1343-1351.

FORSTRÖNEN, P.F. (1963) The origin and the morphogenetic significance of the external granular layer of the cerebellum as determined experimentally in chick embryos. Acta Neurol. Scand. 39:314-316.

FUJITA, S., SHIMADA, M., and NAKAMURA, T. (1966) $\mathrm{H}^{3}$-thymidine autoradiographic studies on cell proliferation and differentiation in the external and 
internal granular layers of the mouese cerebellum. J.Comp.Neurol. 128:191-208.

FUJITANI, Y., FUJITANI, S., LUO, H., QIU, F., BURLISON, J., LONG, Q., KAWAGUCHI, Y., EDLUND, H., MACDONALD, R.J., FURUKAWA, T., FUJIKADO, T., MAGNUSON, M.A., XIANG, M., and WRIGHT, C.V. (2006) Ptf1a determines horizontal and amacrine cell fates during mouse retinal development. Development 133:4439-4450.

GENIS-GÁLVEZ, J.M., PUELLES, L., and PRADA, C. (1977) Inverted (displaced) retinal amacrine cells and their embryonic development in the chick. Exp.Neurol. 56:151-157.

HAYDAR, T.F., KUAN, C.-Y., FLAVELL, R.A., and RAKIC, P. (1999) The role of cell death in regulating the size and shape of the mammalian forebrain. Cereb. Cortex 9:621-626.

HIS, W. (1888) Zur Geschichte des Gehirns sowie der centralen und peripherischen Nervenbahnen beim menschlichen Embryo. Abh.d.math-phys.Kl.d.Königl.Sächs. Ges.d. Wiss. 14:341-392.

HIS, W. (1890) Die Entwicklung des menschlichen Rautenhirns vom Ende des ersten bis zum Beginn des dritten Monats.I. Verlängertes Mark. Abh.d.mathphys.Kl.d.Königl.Sächs.Ges.d.Wiss. 29:1-74.

HIS, W. (1892) Zur allgemeinen Morphologie des Gehirns. Arch.Anat.Physiol., Anat.Abt. 16:346-383.

HIS, W. (1893) Vorschläge zur Eintheilung des Gehirns. Arch.Anat.Physiol., Anat.Abt. 17:172-179.

HIS, W. (1904) Die Entwicklung des menschlichen Gehirns. Engelmann, Leipzig.

KÖLLIKER, A. (1884) Grundriss der Entwickelungsgeschichte des Menschen und der höheren Tiere für Studierende und Ärzte. 2. Edit. Engelmann, Leipzig.

KUAN C.-Y., ROTH K.A., FLAVELL R.A. and RAKIC P. (2000) Mechanisms of programmed cell death in the developing brain. Trends Neurosci. 23:291-297.

KUPFFER, C. VON (1906) Die Morphogenesis des Centralnervensystems. In: Handbuch der vergleichenden und experimentellen Entwicklungslehre der Wirbeltiere, Band 2, Teil 3 (Ed. O.Hertwig) Gustav Fischer, Jena, 1-199.

LI, S., MO, Z., YANG, X., PRICE, S.M., SHEN, M.M., and XIANG, M. (2004) Foxn4 controls the genesis of amacrine and horizontal cells by retinal progenitors. Neuron 43:795-807.

MATHIS, L., BONNEROT, C., PUELLES, L., and NICOLAS, J.F. (1997) Retrospective clonal analysis of the cerebellum using genetic laacZ/lacZmouse mosaics. Development. 124:4089-4104.

MEYNERT, T. (1872) Vom Gehirne der Saugethiere. In: Handbuch der Lehre von den Geweben des Menschen und der Thiere. (Ed. S.Stricker) Vol.II: pp 694808. Leipzig: Engelmann.

ORR, H. (1887) Contribution to the embryology of the lizard. J.Morphol. 1:311-372.

PUELLES, L. and RUBENSTEIN, J.L.R. (2003) Forebrain gene expression domains and the evolving prosomeric model. Trends Neurosci. 26:469-476.

PUELLES, L., MARTÍNEZ-DE-LA-TORRE, M., PAXINOS, G., WATSON, C., and MARTíNEZ, S. (2007) The Chick Brain in Stereotaxic Coordinates: an Atlas featuring Neuromeric Subdivisions and Mammalian Homologies. Academic Press/Elsevier, San Diego.

PRADA, C., PUELLES, L., and GENIS-GÁLVEZ, J.M. (1981) A Golgi study on the early sequence of differentiation of ganglion cells in the chick retina. Anat.Embryol. 161:305-317.

PRADA, C., PUELLES, L., GENIS-GÁLVEZ, J.M., and RAMÍREZ, G. (1987) Two modes of free migration of amacrine cell neuroblasts in the chick retina. Anat.Embryol. 176:281-287.

RAKIC, P. (1971) Neuron-glia relationship during granule cell migration in developing cerebellar cortex. A Golgi and electronmicroscopic study in Macacus rhesus. J.Comp.Neurol. 141:283-312.

RAMÓN Y CAJAL, S. (1888a) Estructura de la retina de las aves. Rev. Trim. Histol. Norm. Patol. 1: 42-49.

RAMÓN Y CAJAL, S. (1988b) Morfología y conexiones de los elementos de la retina de las aves. Rev. Trim. Hist.Norm Patol. 1:11-16.

RAMÓN Y CAJAL, S. (1988c) Estructura del cerebelo. Gaceta Médica Catalana 11:449-457.

RAMÓN Y CAJAL, S. (1889a) Coloración por el metodo de Golgi de los centros nerviosos de los embriones de pollo. Gaceta Médica Catalana 12:6-8.

RAMÓN Y CAJAL, S. (1889b) Nota preventiva sobre la estructura de la médula embrionaria. Gaceta Medica Catalana 12:132.

RAMÓN Y CAJAL, S. (1889c) Nota preventiva sobre la estructura de la médula embrionaria. Gaceta Medica Catalana 12:174.

RAMÓN Y CAJAL, S. (1889d) Contribución al estudio de la estructura de la médula espinal. Rev. Trim. Histol.Norm. Patol.1:79-106.

RAMÓN Y CAJAL, S. (1889e) Sobre las fibras nerviosas de la capa granulosa del cerebelo y evolución de los elementos cerebelosos. Rev. Trim. Histol.Norm. Patol. 1:107-118

RAMÓN Y CAJAL, S. (1889f) Sur la morphologie et les conexions des elements de la retine des oiseaux. Anat.Anz. 4:111-121.

RAMÓN Y CAJAL, S. (1890a) Sur l'origine et les terminations des fibres nerveuses de la moelle embryonaire. Anat.Anz. 5:85-95; 5:111-119.

RAMÓN Y CAJAL, S. (1890b) Sobre la aparicion de las terminaciones celulares en la médula embrionaria. Gaceta Sanitaria de Barcelona 2:413-418.

RAMÓN Y CAJAL, S. (1890c) A quelle epoque apparaissent les expansions des cellules nerveuses de la moelle epiniere du poulet. Anat.Anz. 5: 609-613;5:631 639.

RAMÓN Y CAJAL, S. (1890d) Sur les fibres nerveuses de la couche granuleuse du cervelet et sur l'evolution des elements cerebelleux. Internat.Mschr.Anat.Physiol. 7:12-31.

RAMÓN Y CAJAL, S. (1890e) A propos de certains elements bipolaires du cervelet avec quelques details nouveaux sur l'evolution des fibres cerebelleuses. Internat. Mschr. Anat.Physiol. 7:447-468.

RAMÓN Y CAJAL, S. (1890f) Sobre la existencia de celulas nerviosas epeciales en la primera capa de las circunvoluciones cerebrales. Gaceta Med.Catalana 13 737-739.

RAMÓN Y CAJAL, S. (1891) Sur la structure de l'ecorce cerebrale de quelques mammiferes. La Cellule 7:125-176.

RAMÓN Y CAJAL, S. (1893a) Estructura de la corteza occipital inferior de los pequeños mamíferos. Anales Soc. Hist.Nat. 22:115-125.

RAMÓN Y CAJAL, S. (1893b) La retine des vertebrés. La Cellule 9:121-255.

RAMÓN Y CAJAL, S. (1894a) La fine structure des centres nerveux. The Croonian Lecture, Proc.Roy.Soc.London 55:444-468.

RAMÓN Y CAJAL, S. (1895) Les nouvelles idees sur la structure du systeme nerveux chez l'homme et chez les vertebres.(trans. by L.Azoulay) Paris:Rheinwald.

RAMÓN Y CAJAL, S. (1896) Nouvelles contributions a l'etude histologique de la retine et a la question des anastomoses des prolongements protoplasmiques. J.de l'Anat.et de la Physiol. 33:481-543.

RAMÓN Y CAJAL, S. (1904a) Asociación del método del nitrato de plata al embrionario para el estudio de los focos motores y sensitivos. Trab.Lab.Invest.Biol. 3:65-96.

RAMÓN Y CAJAL, S. (1904b) Une methode simple pour la coloration elective du reticulum protoplasmique. Bibliographie Anatomique 14:1-93.

RAMÓN Y CAJAL, S. (1904c) El retículo neurofibrilar en la retina. Trab.Lab. Invest.Biol. 3:185-212

RAMÓN Y CAJAL, S. (1904d) Das Neurofibrillennetz der Retina Intern.Mschr.Anat.Physiol. 21:369-399.

RAMÓN Y CAJAL, S. (1904e) Contribución al estudio de la estructura de las placas motrices. Trab.Lab.Invest.Biol. 3:97-100.

RAMÓN Y CAJAL, S. (1906) Genese des fibres nerveuses de l'embryon et observations contraires a la theorie catenaire. Trab.Lab.Invest.Biol. 4:219-284.

RAMÓN Y CAJAL, S. (1907) Die histogenetische Beweise der Neuronentheorie von His und Forel. Anat.Anz. 30:113-144.

RAMÓNY CAJAL, S. (1908) Nouvelles observations sur l'evolution des neuroblastes, avec quelques remarques sur l'hypothese neurogenetique de Hensen-Held. Anat.Anz. 32:1-10; 32:65-87.

RAMÓN Y CAJAL, S. (1909) Histologie du Systeme Nerveux de l'Homme et des Vertebres. Vol.I. Reprinted, CSIC, 1954, Madrid. (the French translation of L.Azoulay of the earlier 1904 Spanish edition was variously expanded by Cajal)

RAMÓN Y CAJAL, S. (1910) Algunas observaciones favorables a la hipótesis neurotrópica. Trab.Lab.Invest.Biol. 8:63-134.

RAMÓN Y CAJAL, S. (1911) Histologie du Systeme Nerveux de l'Homme et des Vertebres. Vol.II. CSIC reprint 1954, Madrid. 


\section{L. Puelles}

RAMÓN Y CAJAL, S. (1912a) Fórmula de fijación para la demostración fácil del aparato reticular de Golgi y apuntes sobre la disposición de dicho aparato en la retina, los nervios y algunos estados patológicos. Trab.Lab. Invest. Biol. 10:209220.

RAMÓN Y CAJAL, S. (1912b) La Fotografia de los Colores: Fundamentos Científicos y Reglas Prácticas. Moya, Madrid.

RAMÓN Y CAJAL, S. (1913) Estudios sobre la degeneración y regeneración del sistema nervioso. Vol. I. Moya, Madrid

RAMÓN Y CAJAL, S. (1914) Estudios sobre la degeneración y regeneración del sistema nervioso. Vol. II. Moya, Madrid

RAMÓN Y CAJAL, S. (1914b) Algunas variaciones fisiológicas y patológicas del aparato reticular de Golgi. Trab.Lab.Invest.Biol. 12:127-227.

RAMÓN Y CAJAL, S. (1915) Consideraciones generales sobre la polarización ontogénica y filogénica del aparato de Golgi. Bol.Soc.Esp.Biol. 4:.25-32.

RAMÓN Y CAJAL, S. (1919a) La desorientación inicial de las neuronas retinianas de axón corto (algunos hechos favorables a la concepción neurotrópica). Trab.Lab.Invest.Biol. 17:65-86.

RAMÓN Y CAJAL, S. (1919b) Accion neurotrópica de los epitelios. Trab.Lab.Invest.Biol. 17:181-228+35 fgs.

RAMÓN Y CAJAL, S. (1920) Algunas observaciones contrarias a la hipótesis sincitial de la regeneración nerviosa y neurogénesis normal. Trab. Lab. Invest.Bid. 18:275-302+11 fgs

RAMÓN Y CAJAL, S. (1925) Quelques remarques sur les plaques motrices de la langue des mammiferes. Trab.Lab.Invest.Biol. 23:241-254.

RAMÓN Y CAJAL, S. (1929) Etudes sur la neurogenese de quelques vertebres. Moya, Madrid. An English translation of this work by L.Guth was published by Thomas (Springfield, Illinois) in 1960.

RAMÓN Y CAJAL, S. (1933) ¿Neuronismo o reticularismo?: Las pruebas objetivas de la unidad anatómica de las células nerviosas. Archiv.Neurobiol., 13 (2 and 4-6) (reedited in 1952 by Cajal Institute, CSIC).

RETZIUS, G. (1893) Die Cajal'schen Zellen des Grosshirnrinde beim Menschen und bei Saugethiere. Biol.Unters., Neue Folge, 6:113-173.

SANES, D.H., REH, T.A., and HARRIS, W.A. (2000) Development of the Nervous
System. Academic Press, San Diego.

SCHAPER, A. (1897) The earliest differentiation in the central nervous system of vertebrates. Science 5:430-431.

TELLO, J.F. (1903) Sobre la existencia de neurofibrillas gigantes en las neuronas de los reptiles. Trab.Lab. Invest.Biol. 2:223-225.

TELLO, J.F. (1904) Las neurofibrillas en los vertebrados inferiores. Trab.Lab. Invest.Biol. 3:113-151.

TELLO, J.F. (1906) Terminaciones sensitivas en los pelos y otros órganos. Trab.Lab. Invest.Biol. 4:49-77.

TELLO, J.F. (1917) Génesis de las terminaciones motrices y sensitivas Trab.Lab. Invest. Biol. 15:101-199.

TELLO, J.F. (1922) Las diferenciaciones neuronales en el embrión de pollo, durante los cuatro primeros dias de la incubación. In: Libro en Honor a S. Ramón y Cajal. I., CSIC, Madrid, pp 205-250.

TELLO, J.F. (1923) Les différenciations neuronales dans l'embryon de poulet, pendant les premiers jours de l'incubation. Trab.Lab.Invest. Biol. 21:1-94.

TELLO, J.F. (1934a) Les differenciations neurofibrilaires dans le prosencephale de la souris de 4 a 15 millimètres. Trab.Lab.Invest. Biol. 29:339-396.

TELLO, J.F. (1934b) Beitrag zur Kenntnis der Entwicklung des Corpus mamillaire bei der Maus. Zeitsch.Mikr.anat.Forsch. 36:622-630.

TELLO, J.F. (1935) Evolution des formations neurofibrilaires dans l'ecorce cérebrale du fœtus de souris blanche depuis les $15 \mathrm{~mm}$ jusqu'à la naissance. Trab.Lab. Invest. Biol. 30:477-528.

TELLO, J.F. (1936) Quelques données embryologiques qui contribuent a l'eclaircissement de la constitution du fornix longus. Arch.Port.Scs.Biol. 29:339396.

TELLO, J.F. (1936-1937) Evolution, structure et connexions du corps mammilaire chez la souris blanche, avec des indications chez d'autres mamiféres. Trab.Lab.Invest. Biol. 31:76-142.

TELLO, J.F. (1938) Histogenèse du cervelet et ses voies chez la souris blanche. Trab.Lab.Invest. Biol. 32:1-74.

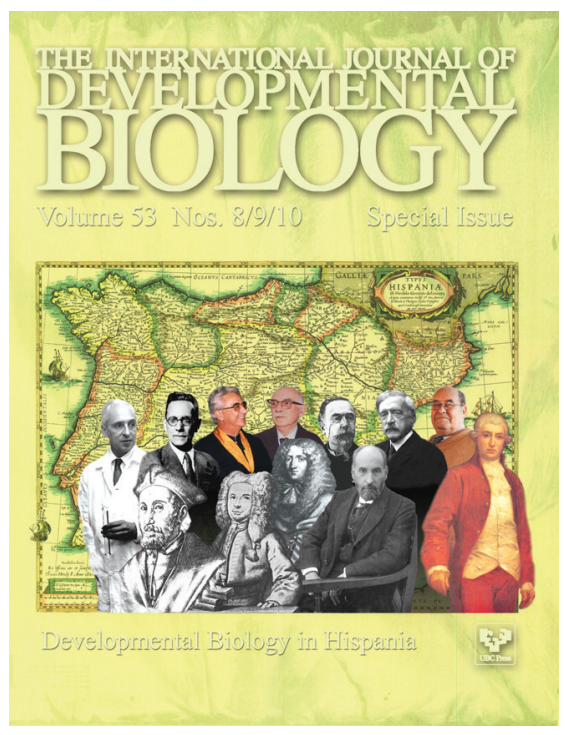




\section{Further Related Reading, published previously in the Int. J. Dev. Biol.}

See our recent Special Issue Epigenetics \& Development edited by Saadi Khochbin and Stefan Nonchev at: http://www.ijdb.ehu.es/web/contents.php?vol=53\&issue=2-3

See Special Issue Pattern Formation edited by Michael K. Richardson and Cheng-Ming Chuong at: http://www.ijdb.ehu.es/web/contents.php?vol=53\&issue=5-6

Cell cycle control of Notch signaling and the functional regionalization of the neuroepithelium during vertebrate neurogenesis

Maria Jesús Latasa, Elsa Cisneros and Jose María Frade

Int. J. Dev. Biol. (2009) 53: 895-908

Axon guidance in the inner ear

Donna M. Fekete and Andrea M. Campero

Int. J. Dev. Biol. (2007) 51: 549-556

Axon guidance receptors direct growth cone pathfinding: rivalry at the leading edge. Helen M Cooper

Int. J. Dev. Biol. (2002) 46: 621-631

Early neurogenesis in Amniote vertebrates.

N M Le Douarin

Int. J. Dev. Biol. (2001) 45: 373-378

Cell-cell signaling during neurogenesis: some answers and many questions.

K M Bhat

Int. J. Dev. Biol. (1998) 42: 127-139

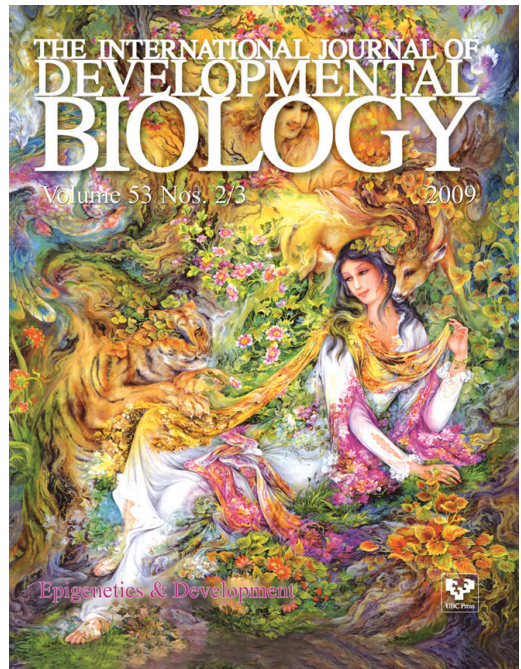

5 yr ISI Impact Factor $(2008)=3.271$

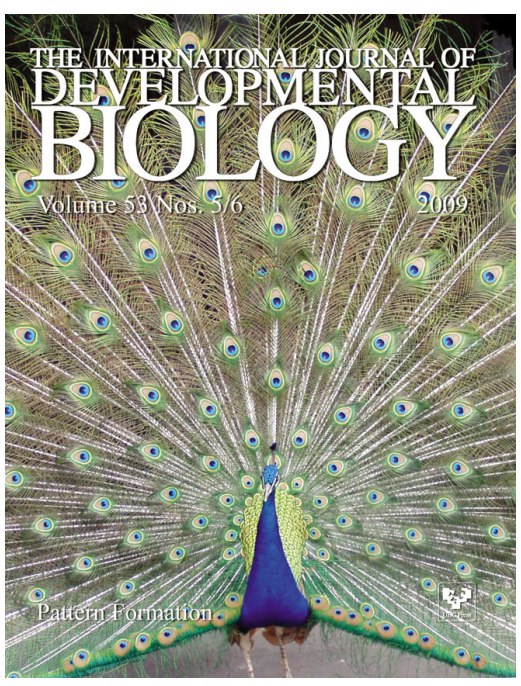

